\title{
Key hydrological processes in the Del Azul Creek basin, sub-humid Pampean Plain
}

\author{
M.E. Zabala ${ }^{\mathrm{a}, \mathrm{b}, \mathrm{c}, *}$, M. Gorocito $^{\mathrm{a}, \mathrm{d}}$, S. Dietrich ${ }^{\mathrm{a}, \mathrm{b}, \mathrm{c}}$, M. Varni $^{\mathrm{a}, \mathrm{c}}$, R. Sánchez Murillo ${ }^{\mathrm{e}}$, M. Manzano ${ }^{\mathrm{f}}$, E. Ceballos ${ }^{\mathrm{a}, \mathrm{b}}$ \\ a Instituto de Hidrología de Llanuras “Dr. Eduardo J. Usunoff” (IHLLA), República de Italia 780, Azul, Buenos Aires, Argentina \\ b Consejo Nacional de Investigaciones Científicas y Técnicas (CONICET), Av. Rivadavia 1917, Ciudad Autónoma de Buenos Aires, Argentina \\ c Universidad Nacional del Centro de la Provincia de Buenos Aires, Pinto 399, Tandil, Buenos Aires, Argentina \\ d Agencia Nacional de Promoción Científica y Tecnológica, Godoy Cruz 2370, Ciudad Autónoma de Buenos Aires, Argentina \\ e Stable Isotopes Research Group and Water Resources Management Laboratory, Universidad Nacional, Heredia 86-3000, Costa Rica \\ ${ }^{\mathrm{f}}$ Escuela de Ingeniería de Caminos, Canales y Puertos y de Ingeniería de Minas, Universidad Politécnica de Cartagena, P ${ }^{\circ}$ de Alfonso XIII 52, E-30203 Cartagena, Spain
}

\section{H I G H L I G H T S}

- The water salinization limits its use.

- Stable isotopes revealed rechargebiased towards summer and spring seasons.

- Hydrochemistry is controlled by evaporation and surface-groundwater interaction.

- A novel conceptual hydrogeological model is presented for a large subhumid plain.

\section{A R T I C L E I N F O}

\section{Article history:}

Received 13 July 2020

Received in revised form 3 September 2020

Accepted 5 September 2020

Available online 12 September 2020

Editor: Damia Barcelo

\section{Keywords:}

Hydrological-physical processes

Stable isotopes

Rainwater

Surface water

Groundwater

Pampeano Aquifer

\section{G R A P H I C A L A B S T R A C T}

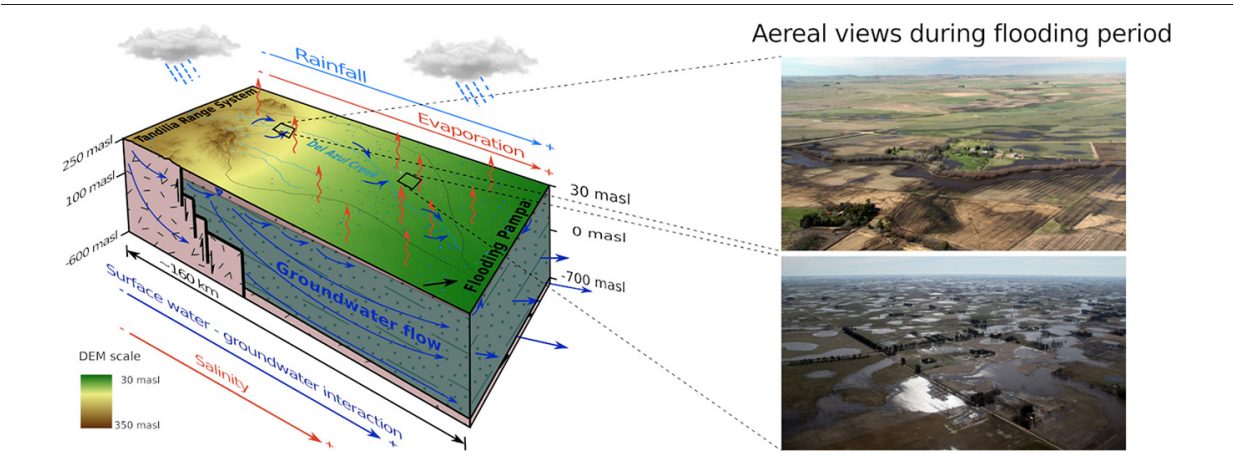

\begin{abstract}
A B S T R A C T
Groundwater plays an important role in the economic development of the Chaco-Pampean Plain (Argentina), where industry, agriculture and cattle farming are the main economic activities. The $66 \%$ of the country's population lives in this area. The low slopes of this region condition the water movement and the occurrence of physical and chemical processes. The aim of this work is to update the hydrological conceptual model of the Del Azul Creek basin (Buenos Aires Province), a sub-humid and continental plain, using environmental tracers. In total, the study was based on the analysis of 201 samples (stable isotopes) and 184 samples (chemical data) including rainwater, surface water and groundwater. The temporal and spatial variation in the isotopic composition of rainfall and the hydrological physical-processes, evaporation, surface water-groundwater interaction and recharge were studied. Isotopic compositions of rainfall revealed a seasonal variation across the basin. Low $\delta^{18} \mathrm{O}$ rainfalls occur during the coldest seasons, while high $\delta^{18} \mathrm{O}$ rainfalls occur during the warmest seasons. The isotopic compositions of rainfall varied only during the cold period in the upper basin. At this time, the lowest $\delta^{18} \mathrm{O}$ rainfall fell in the upper basin, while in the other areas and during the warmer seasons, no differences were observed. Evaporation was a relevant process in the flatter area of the basin, mainly during the warmest seasons. Samples taken from the wetlands and from the lower section of the Del Azul Creek were strongly evaporated. In the first $30 \mathrm{~m}$ depth of the aquifer, groundwater reflected the isotopic composition of rainfall from the warmest seasons, thus revealing seasonal preferential recharge and a good hydraulic connection. This study provides direct evidence showing that both evaporation and the surface water-groundwater interaction are processes that play a key role in the control of the isotopic and chemical composition of water.
\end{abstract}

(c) 2020 Elsevier B.V. All rights reserved.

\footnotetext{
* Corresponding author at: Instituto de Hidrología de Llanuras “Dr. Eduardo J. Usunoff” (IHLLA), República de Italia 780, Azul, Buenos Aires, Argentina.

E-mail addresses: mzabala@ihlla.org.ar, mzabala@faa.unicen.edu.ar (M.E. Zabala).
} 


\section{Introduction}

Growth in global population as well as climate change lead to direct and indirect impacts inducing abrupt land use changes (Wiebe et al., 2015). All these changes affect freshwater quality and availability, and governments should find a balance between supply and demand. In this new context, the scientific community needs to understand how hydrological processes control the water movement, its quality and quantity in different environments. According to UNESCO (2011), more than half of the world's population relies on the freshwater that is generated in mountain regions. Hence, the study of hydrological processes in arid/semiarid mountain catchments through the use of isotopic tracers has drawn considerable attention over the last decades. Previous studies have addressed conventional hydrological scenarios featured by slopes greater than $0.5 \%$, with well-defined basin boundaries and drainage networks. Most of these studies have focused on the identification of water recharge sources (Yin et al., 2011; Boukhari et al., 2014; Farid et al., 2014; Gonzales Amaya et al., 2018; Ma et al., 2018; Oiro et al., 2018; Barberá et al., 2018; Bahir et al., 2019); the estimation of aquifers recharge/discharge and water evaporation rates (Mayr et al., 2007; Yuan et al., 2011; Qian et al., 2014); the study of the effect of seasonal rainfall patterns on the isotopic composition of surface water and groundwater (Bajjali, 2006; Dogramaci et al., 2012; Hoke et al., 2013; Singh et al., 2013; Peng et al., 2015; Jódar et al., 2016; Bershaw and Lechler, 2019); and the study of the interactions between surface water and groundwater (Oyarzún et al., 2016; Wu et al., 2017).

In contrast, large plains (e.g., Great Plains in Canada and US; Pannonian Steppe in Hungary; North China Plain; Chaco-Pampean Plain in Argentina) pose an inherent challenge since complete hydrological characterization is often constrained by large-scale heterogeneities. The Chaco-Pampean Plain encompasses 120 million ha, comprising approximately $66 \%$ of the country's population (26,500 million) (INDEC, 2010). It is the strongest economic region in Argentina, where industry, agriculture, and cattle farming are the main economic activities. This region is characterized by remarkable low slopes $(<0.1 \%)$. Drainage networks and boundaries are not well defined; however, rivers and creeks have a permanent flow regime, indicating a persistent baseflow connection to groundwater reservoirs. During wet periods, surplus of surface water flows over the wide alluvial plains in the form of non-concentrated overland flow. A fraction of this water is accumulated in shallow depressions, where water is subjected to evaporation and infiltration, thus replenishing soil moisture storage with a potentially high $\delta^{18} \mathrm{O}$ composition. If rainfall is sufficient and has high intensity, then i) groundwater recharge occurs, ii) surface runoff increases, and iii) shallow depressions build up to the point of connecting to each other to finally discharge into the main river channels (Varni, 2013; Entraigas et al., 2017).

In Argentina, studies on the isotopic composition of rainfall started with Panarello and Albero (1983) and Panarello and Parica (1984). The weighted average annual isotopic composition of rainfall in Buenos Aires city (Ciudad Universitaria station) (1978-1999) were $\delta^{18} \mathrm{O}=$ $-5.5 \%$ and $\delta^{2} \mathrm{H}=-30 \%$. The local meteoric water line (LMWL) was calculated as: $\delta^{2} \mathrm{H}=8 \delta^{18} \mathrm{O}+14 \%$ (Panarello et al., 1998; Dapeña and Panarello, 1999). Dapeña and Panarello (2004) observed heavier isotopic contents in the coldest months (May-August) than in the warmest ones (February-May). This pattern was also observed in other Argentinean cities such as Santa Fe (Santa Fe Province), Corrientes (Corrientes Province) and Azul (Buenos Aires Province). Martínez et al. (2011) characterized the isotopic composition of rainwater in the southern part of the Tandilia Range System (Buenos Aires Province) using 7 monthly composite passive collectors for the period 2005-2010. The arithmetic average for all stations was $\delta^{18} \mathrm{O}=-5.1 \%$ and $\delta^{2} \mathrm{H}=-30 \%$, with a LMWL described as: $\delta^{2} \mathrm{H}=8.05 \cdot \delta^{18} \mathrm{O}+11.10 \%$. Similarly, several surface water and groundwater isotopic studies have been conducted across the Buenos Aires Province to understand water movement and to identify the salinity origin (Quiroz Londoño et al., 2008; Romanelli et al., 2010; Carretero et al., 2011; Glok Galli et al., 2011; Martínez et al., 2011; Carretero et al., 2013; Martínez et al., 2013; Martínez et al., 2016; Armengol et al., 2017, among others). In the Del Azul Creek basin (DACB, Buenos Aires Province), rainfall isotopic studies were initiated by Dapeña et al. (2010). From 1998 to 2007 a station was operated in Azul city as part of the Global Network of Isotopes in Precipitation (GNIP). The LMWL for Azul city was calculated as: $\delta^{2} \mathrm{H}=8 \cdot \delta^{18} \mathrm{O}+13 \%$ 。 $(n=116$ monthly samples). Subsequently, rainwater and groundwater isotopic studies continued with Zabala et al. $(2011,2015,2016)$ with the aim of understanding the origin of groundwater and its salinity.

Due to favorable natural conditions, the existence of fertile soils and an acceptable transport network, over the last years several governmental institutions have been promoting investment projects related to agriculture and mining in order to encourage the economic development of the DACB region. But these projects are not accompanied by plans to ensure adequate management of landscape and water resources (Zabala et al., 2015). Within this framework, the aim of this work is to update the hydrological conceptual model (Varni, 2013; Zabala et al., 2016) using environmental tracers to improve the existing knowledge on how hydrological processes govern water movement and its quality in the DACB, a sub-humid continental plain basin. The specific objectives of this work are: (i) to characterize the chemical and isotopic composition of rainwater, surface water and groundwater; (ii) to analyse the seasonal and spatial variation of stable isotopes in rainwater; (iii) to understand the main hydrological physicalprocesses governing water flows which control the water chemical and isotopic composition.

\section{Study area}

\subsection{Regional setting}

The DACB is located within the Chaco-Pampean Plain in Buenos Aires Province (Argentina) between $36^{\circ} 00^{\prime}$ and $37^{\circ} 20^{\prime} \mathrm{S}$ and between $60^{\circ} 15^{\prime}$ and $58^{\circ} 45^{\prime} \mathrm{W}$, and it is part of the Salado River basin (Fig. 1). The Buenos Aires Province concentrates 38\% of the Argentina's population (17,000,000 inhabitants) and the productive activities contribute to 35\% of Argentina's GNP (Consejo Nacional de Coordinación de Políticas Sociales, 2019). The DACB covers an area of $6237 \mathrm{~km}^{2}$ and has a population of 65,280 inhabitants (INDEC, 2010).

This basin is located between the Tandilia Range System to the SW and the Salado River valley to the NE, and $72 \%$ of the area corresponds to a typical sub-humid large plain landscape (Migueltorena et al., 2009). The lower basin is part of the Flooding Pampa (also known as 'Pampa Deprimida'), which is characterized by the presence of extreme flatness, permanent and temporary ponds, and the extensive development of alkaline soils (Zabala et al., 2016). The distribution of human activities is strongly conditioned by geology, soils and the chemical composition of groundwater. The main economic activity in the upper-middle basin is agriculture, which is based on soy, wheat, corn, and sunflower, while in the lower part extensive livestock farms are present. Agriculture is performed mostly as a non-irrigated practice but some irrigation is applied in some specific fields. Other important activities in the upper sector include cattle fattening and dairy farming, and mining. There have been significant land use changes over the last decades. The natural system has been highly altered by agriculture and livestock expansion, resulting in original pastures being replaced by annual crops and/or introduced pastures. The adoption of agricultural technologies (e.g., agrochemicals, no-tillage and irrigation systems) has led to an important advance of the agricultural frontier into previously uncultivated sectors. There has also been an important decrease in livestock area (from 511,800 ha in 1995 to 302,800 ha in 2011 ), which represents $41 \%$ of surface reduction. At the same time, the surface dedicated to agricultural activities has increased 


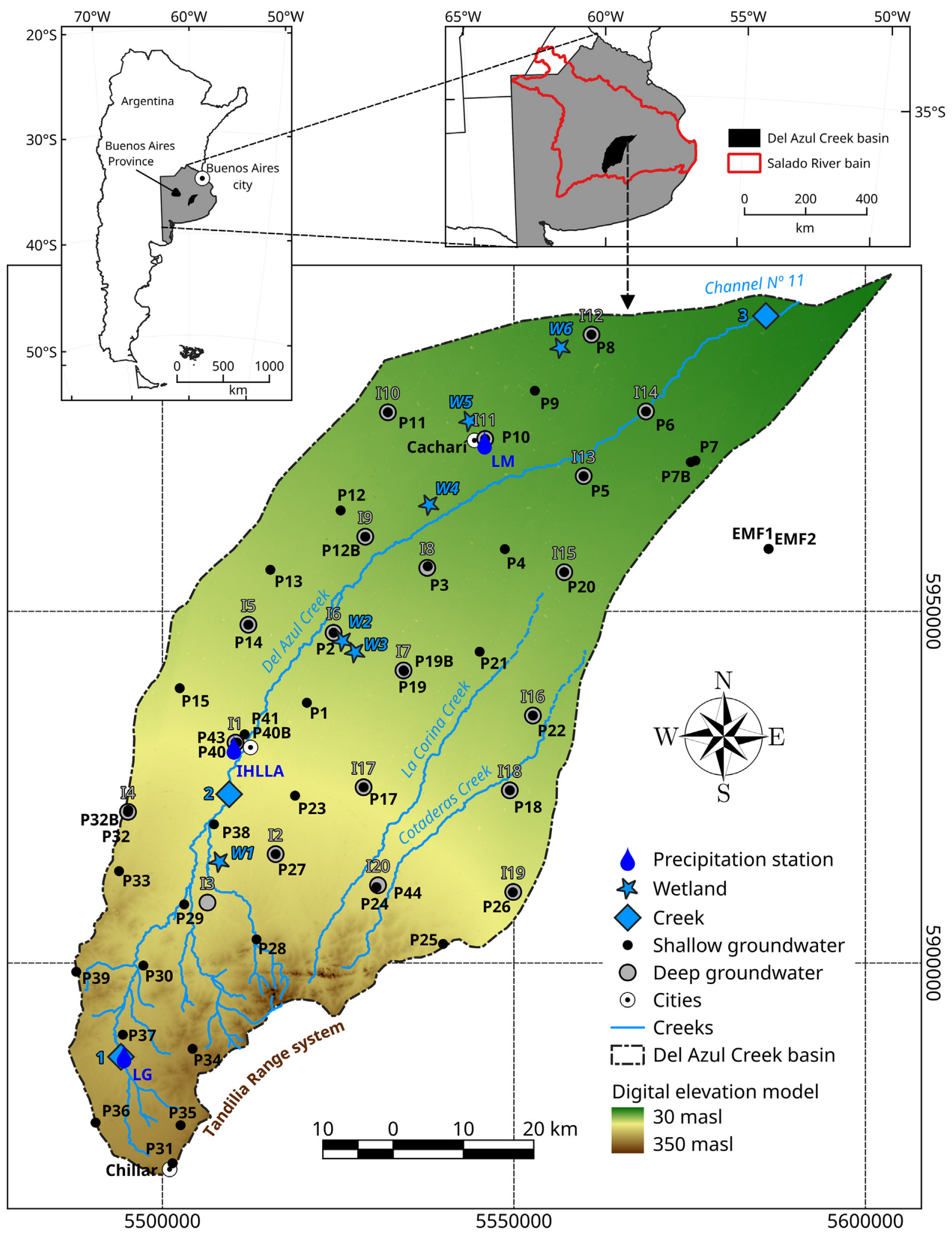

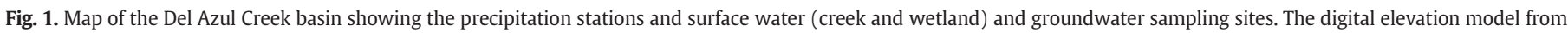
Instituto Geográfico Nacional - IGN (30 m resolution) was included.

considerably (from 129,000 ha in 1995 to 351,900 ha in 2011), which is equivalent to $173 \%$ (Vazquez et al., 2016).

The main groundwater withdrawal in the basin is used for human consumption in the Azul city, which has about 55,728 inhabitants (INDEC, 2010). The mean annual volume that was extracted during the last five years by the water company was $10 \mathrm{hm}^{3}$. The basin also encompasses two other small villages (Chillar in the southernmost part of the basin and Cacharí, in the north), with 3000 inhabitants each, which use less than $0.5 \mathrm{hm}^{3}$ of the annual water consumption.

From the topographical point of view, the DACB can be divided into upper, middle, and lower basin areas. Altitude ranges from 300 masl in the SW to around 40 masl in the NE. Surface slopes average $5 \%$ for the 
upper basin, $0.5-0.8 \%$ for the middle basin, and $0.2 \%$ for the lower basin (Sala et al., 1987). The Del Azul Creek flows along $160 \mathrm{~km}$ from the SW to the NE, where it is drained by the artificial Channel No. 11, which, in turn, constitutes the northern most limit of the study area. In the past, before Channel No. 11 was built, the Del Azul Creek discharged naturally to the Salado River to the N, through a system of shallow lagoons and lowlands, as a result of the negligible slopes that characterize this part of the basin (Entraigas et al., 2004). This lack of slope prevented the creek from eroding its own riverbed and favoring the development of an anarquic drainage network where rivers lost identity. After excavation of Channel No. 11, waters from the Del Azul Creek were led to the Argentine Sea. It should also be noted that, as a consequence of an almost non-existent lateral slope, the Del Azul Creek can drain only a small fraction of the lower basin. Therefore, the other two creeks of the lower basin (Cortaderas and La Corina) run parallel to it until they are lost in the plain (see Fig. 1).

On the other hand, during wet periods, many lagoons located in the middle and lower parts of the basin fill up, join each other and the water begins to move slowly like a mantle flow. Many of these shallow depressions, which are of aeolian origin, are aligned parallel to the Del Azul Creek. The depth to groundwater table is from $<1 \mathrm{~m}$ to the soil surface in the lower basin, from 2 to $4 \mathrm{~m}$ in the middle basin and from 3 to $6 \mathrm{~m}$ in the upper basin (Varni et al., 2013). Under these hydrological and topographic conditions, surface water losses occur by evaporation and infiltration.

Based on Thornthwaite's classification, the study area is categorized as humid to sub-humid, mesothermal, with little or no water deficiency. North of the parallel $40^{\circ} \mathrm{S}$ the Andes Range blocks the moisture from the Pacific Ocean (W), so at this latitude the moisture comes mainly from the Atlantic Ocean and decreases from E to W (Barros and Perczyk, 2006). In the DACB the spatial distribution of rainfall is highly heterogeneous. Large amount differences have been observed over distances of $50-60 \mathrm{~km}$, thus it may be raining in one sector while in another it may not. Due to this heterogeneity, in 2005 a flood early warning system was installed by the IHLLA (Instituto de Hidrología de Llanuras "Dr. Eduardo J. Usunoff) in the upper basin (Cazenave and Vives, 2014). Rainfalls increase from SE (922 mm - Trapenses station) to NW (1066 mm - Campodónico station) across the DACB (Fig. 2). From March to August (coldest seasons) the amount of precipitation increases from SW to NE, while from September to February (warmest seasons) it increases from SE to NW (Varela et al., 2002). Regarding wind directions, in this region they come from the South Atlantic anticyclone and consequently the predominant directions are from the NE and to a lesser extent from the E (Barros and Perczyk, 2006). Actual evapotranspiration across the basin ranges between 70 and $78 \%$ of annual rainfall, with the highest value at the lower basin (Varni and Custodio, 2013).

Average annual rainfall at La Germania station (LG, upper basin; period 2003-2015) is $757 \mathrm{~mm}$ (Fig. 1). Average annual rainfall at Azul station (Servicio Meteorológico Nacional; SMN; middle basin; period 1901-2019) is $911 \mathrm{~mm}$, and average annual temperature is $14.4^{\circ} \mathrm{C}$ (period 1966-2019). Fig. 3 shows the distribution of average monthly rainfall in the upper (LG) and middle (SMN) basins. In the upper basin, the driest months are June $(31 \mathrm{~mm})$ and July $(42 \mathrm{~mm})$, while the wettest months are January $(93 \mathrm{~mm})$ and February $(83.5 \mathrm{~mm})$. In SMN station, the driest months are June, July, and August (45, 45 and $46 \mathrm{~mm}$, respectively), while the rainy months are January, February and March (93, 90 and $118 \mathrm{~mm}$, respectively).

According to Sarochar et al. (2005), although convective rainfalls are less frequent than stratiform rainfalls in the humid pampa, they are likely to be more abundant. The frequency of convective rainfall is higher between November and April (warm months). The two main maxima (highest amount of rainfall) occur between January and April and between October and November. Precipitation shows a strong decrease in the cold months, and its origin is mainly stratiform.

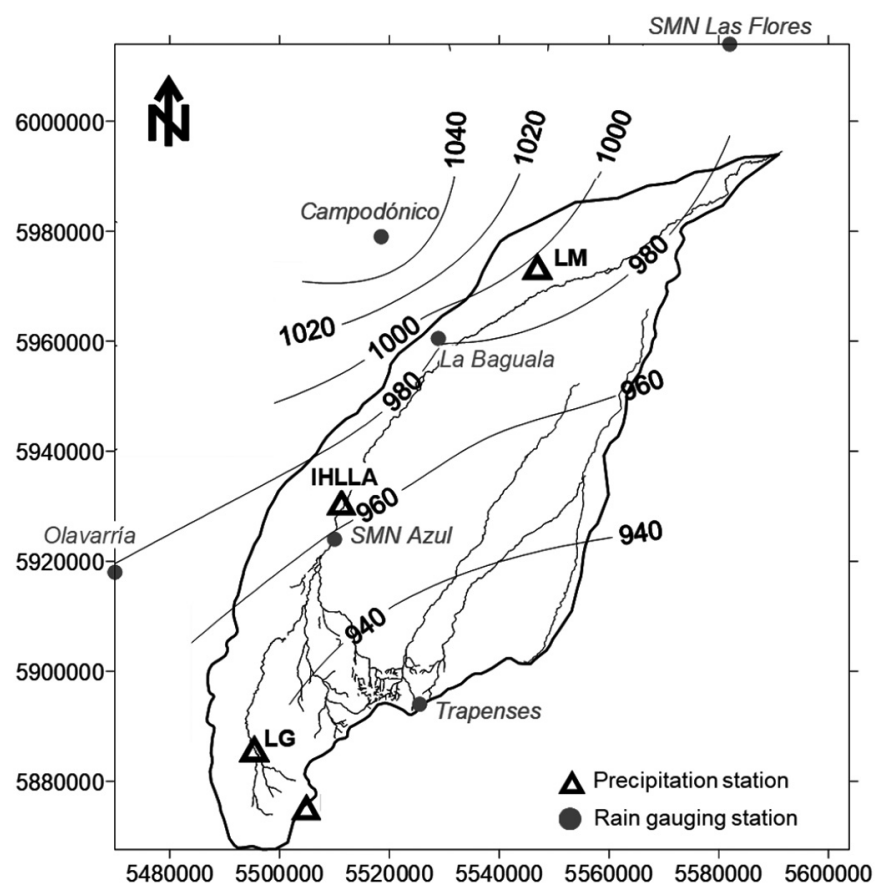

Fig. 2. Spatial distribution of average annual precipitation ( $\mathrm{mm}$ ) for the period 1990-2011 (Zabala, 2013).

\subsection{Geology, geomorphology and soils}

The DACB is a sedimentary aeolian and fluvial basin. Two geological units comprise the surface geology, the Postpampeano and the Pampeano sediments (Fidalgo et al., 1991). The Postpampeano Sediments are formed by La Postrera and Luján formations. La Postrera Formation (Later Pleistocene) consists of aeolian sands and silts (loess) with high contents of volcanic-derived particles. The greatest thicknesses of loess are found in the upper basin, while in the lower basin it is replaced by sediments of the Lujan Formation. The Lujan Formation (Later Pleistocene-Holocene) is composed of alluvial deposits and reworked loess, with dominance of finer textures. The Pampeano Sediments (Pleistocene-Holocene) are composed of sandy and clayey silts with a significant content of volcanic ash. In both units calcrete layers, nodules and calcareous concretions (locally known as tosca) are also present (Zárate and Mehl, 2010). The aeolian sediments were deposited over a Precambrian crystalline basement that crops out to the SW border of the DACB and deepens towards the NE, going from 10-20 m to 800 m depth (Zabala et al., 2009).

The geomorphology of the DACB comprises two major domains: a) the mountain ranges (upper basin) and b) the lowlands (middlelower basin). In the lowland domain, three morpho-sedimentary areas with some hydrological relevance have been recognized: (1) aggradation plain with aeolian sand cover, located in the east middle basin and with the best conditions for water infiltration; (2) aggradation plain with stratiform calcareous crust, located in the west middle basin, whereby calcareous crust generates poor conditions for drainage and favors flooding; (3) alluvial aggradation plain, located in the east of the middle basin and towards the lower basin sector (Zárate and Mehl, 2010). This area has a very low gradient and is part of the Flooding Pampa. Several aeolian landforms such as dunes, loess mantle and shallow deflation basins were described in the lowland domain. The dunes system is oriented NE-SW and together with deflation basins play a relevant role during runoff. Hapludolls soils were developed over the dunes, while in inter-dune areas which act as drainage lines, there are halo-hydromorphic soils (Taboada, 2006). In addition, soils developed in this region show evidence of poor internal drainage and high sodium content (Lavado and Taboada, 1988). In the middle and lower basins, 

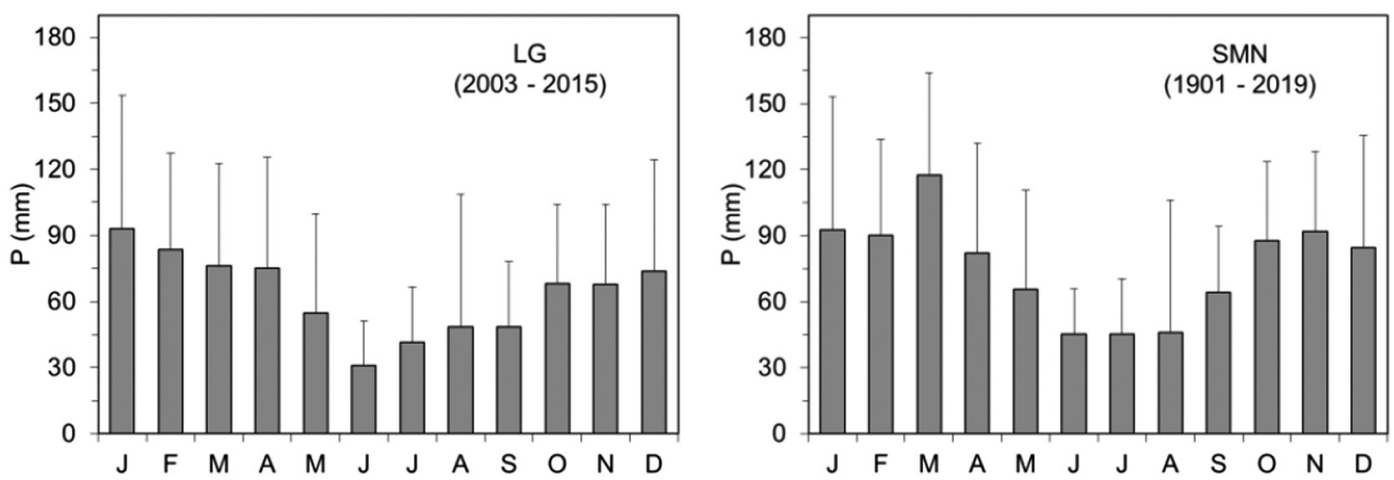

Fig. 3. Distribution of average monthly precipitation ( $\mathrm{mm}$ ) for the indicated period at the LG (upper basin) and SMN (middle basin, Azul city) stations.

the dominant soils are Natraquolls and Natraqualfs, in which the presence of the argillic horizon (i.e., restrictive layer) prevents vertical drainage and favors seasonal flooding. Deflation basins are usually occupied by temporary shallow water bodies fed by rain and/or groundwater. In this work, deflation basins were called wetlands.

\subsection{Hydrogeology}

The Pampeano Aquifer is formed by the Postpampeano and Pampeano sediments. The water table is shallow and varies between $<1 \mathrm{~m}$ in the lower basin and $6 \mathrm{~m}$ depth in the upper basin and reproduces the seasonal recharge pattern (Varni et al., 2013). This particular situation of shallow groundwater table favors the evaporation/evapotranspiration directly from the aquifer. The Pampeano Aquifer is recharged by rainfall mainly in autumn and spring, being the basin headwaters the principal area of recharge. Local recharge is also important along the entire basin and replenishes the upper part of this multiunit aquifer. Annual recharge rates range from $20 \%$ in the upper basin to $<10 \%$ in the lower one, with values between 10 and $20 \%$ in the middle basin (Varni, 2013). Specific yield ranges between 7 and 10\% whereas the hydraulic conductivity varies between 1 and $10 \mathrm{~m} / \mathrm{d}$ (Varni et al., 2013; Dietrich et al., 2018).

In the upper basin, only local recharge occurs and discharge is represented as baseflow. In this region, the bedrock is near the soil surface $(\sim 10 \mathrm{~m})$ and the effective average groundwater flow velocity is about $10 \mathrm{~m} / \mathrm{d}$. In the middle basin, discharge occurs as a baseflow and as a regional groundwater flow. Discharge amounts vary according to the fluctuations of the phreatic levels, which range from 2.5 to $4 \mathrm{~m}$. The regional groundwater flow begins in the transition zone $(\sim 100 \mathrm{~m}$ of aquifer thickness) and it is out of the zone of influence of surface water courses, thus there is limited baseflow discharge. The effective average flow velocity is $1.5 \mathrm{~m} / \mathrm{d}$. Here, downward vertical flows dominate, except for some sectors close to surface water bodies. In the lower basin, the phreatic levels are very shallow (less than $2 \mathrm{~m}$ ) and therefore, groundwater and surface water exchange is a significant and dynamic process. The effective average flow velocities vary between 0.1 and $0.01 \mathrm{~m} / \mathrm{d}$, decreasing as water moves to the $\mathrm{N}$. In the flatland, the regional flow system has a significant thickness, thus a regional groundwater flow is quite more relevant than local systems in terms of the water volume transported (Varni, 2013).

Potentiometric data of the first $30 \mathrm{~m}$ depth of the Pampeano Aquifer indicate that horizontal groundwater flow is from SW to NE. All across the basin, both the creeks and the wetlands are fed by local groundwater flows, whose contribution varies in relation to the depth of the phreatic level. For the upper basin, Guevara Ochoa et al. (2019) obtained that the average annual discharge of groundwater to the creek is $34 \mathrm{~mm}$, while the average annual recharge of the creek to the aquifer is $1.4 \mathrm{~mm}$. According to the authors, monthly groundwater discharges are higher in winter-spring (July to December, with an average of
$3.3 \mathrm{~mm}$ ) and lower in summer-autumn (January to June, with an average of $2.8 \mathrm{~mm}$ ).

Water chemical types evolve from $\mathrm{Ca} / \mathrm{Mg}-\mathrm{HCO}_{3}$ in the upper basin to $\mathrm{Na}-\mathrm{HCO}_{3}$ in the middle part, and to $\mathrm{Na}-\mathrm{ClSO}_{4}$ and $\mathrm{Na}-\mathrm{Cl}$ in the lower basin. The main hydrogeochemical processes controlling the chemical composition in the first $30 \mathrm{~m}$ depth of the Pampeano Aquifer are a) dissolution of soil $\mathrm{CO}_{2}$, carbonate and silicate minerals; b) cationic exchange with Na release and Ca uptake; and c) possible clay formation. The groundwater salinity spatial pattern is consistent with the potentiometric one, increasing strongly from SW to the NE. In the middle and lower basin areas, evaporation is a relevant process in the water salinity increase (Zabala et al., 2015).

\section{Materials and methods}

\subsection{Sampling and analytical methods}

Three integrating wet/dry precipitation collectors and rain gauging stations were installed at different altitudes in the upper (La Germania - LG, near Chillar city), middle (IHLLA, in Azul city) and lower basin (La Madrugada - LM, in Cacharí city), ranging from 221 to 72 masl, respectively (Fig. 1). The sampling period was from March 2010 to September 2019. Passive precipitation collectors consisted of a $26.5 \mathrm{~cm}$ diameter plastic funnels connected to 20 L plastic containers. Containers with a mineral oil thin-layer were buried underground to avoid secondary evaporation. Monthly rainfall amounts were recorded using automated weather stations with remote data transmission (LG), they were provided by Servicio Meteorológico Nacional (IHLLA), or they were conducted manually (LM). Although precipitation samples were collected monthly, they were integrated into six-month composites samples for isotopic and physico-chemical analyses. Fifty seven physico-chemical analyses (March 2010-March 2019) and fifty one stable isotopes $\left(\delta^{18} \mathrm{O}\right.$ and $\left.\delta^{2} \mathrm{H}\right)$ analyses (March 2011-September 2019) were conducted.

Three surface water sites were sampled for isotopic and physicochemical analyses $(n=6)$ along the Del Azul Creek in February 2018 (summer season) and November 2018 (spring season) (Fig. 1). The superficial flow rates were measured in all the sampling campaigns. In Site 1 (La Germania), the flow rate was measured with an OTT MF proWater Flow Meter equipment, in Sites 2 (Seminario - upstream Azul city) and 3 (Gualicho - lowest sector), flow rates were calculated by rating curves of the corresponding control sections. In addition, six wetlands were sampled (W1-W6, Fig. 1) in September 2019 (spring season) for isotopic and physico-chemical analyses. In all the surveys the electrical conductivity (EC), $\mathrm{pH}$, and water temperature (T) were measured on site using a multi-parameter probe Oakton PCSTestr35.

The IHLLA's groundwater monitoring network is composed of 66 boreholes clustered in shallow and deep, but since 2017 only 29 boreholes have been sampled every six months (Fig. 1). Shallow boreholes 
(3-10 $\mathrm{m}$ ) are screened in their last meter, while in the deep (30 m) boreholes screens are located between 25 and $30 \mathrm{~m}$ depth. Commonly, groundwater samples are collected after purging at least three times the borehole water volume and after EC, $\mathrm{pH}$ and $\mathrm{T}$ T were stabilized. These parameters were measured by a multi parameter probe (Oakton PCSTestr 35) and inside a flow-through cell. Alkalinity was also measured by acidic titration in the field. In this study, 115 physicochemical analyses from four 2018 and 2019 sampling campaigns were combined for further study. A total of 138 stable isotope analyses, from 8 previous $(n=107)$ and new $(n=31)$ surveys (August 1999, December 2000, February 2007, August 2010, December 2010, June 2011, October 2011 and September 2019) were also combined to have a better representation of the system.

Chemical analyses of integrating precipitation water, surface water, and groundwater were conducted at the IHLLA Laboratory following the methodology proposed by the American Public Health Association (APHA, 2012), and using the following methods: $\mathrm{Ca}^{2+}, \mathrm{Mg}^{2+}, \mathrm{Na}^{+}$ and $\mathrm{K}^{+}$were analysed by flame atomic absorption spectrometry (EAA SHIMADZU AA6800) with SM 3111 method; $\mathrm{SO}_{4}^{2-}$ by ultraviolet spectrophotometer screening (Thermo Aquamate) with EPA 9038 method; $\mathrm{Cl}^{-}$by titration with SM 4500-Cl B method; $\mathrm{NO}_{3}^{-}$by ultraviolet spectrophotometer screening (Thermo Aquamate) with SM 4500 B-C method; $\mathrm{CO}_{3}^{-}$and $\mathrm{HCO}_{3}^{-}$(expressed in this work as alkalinity) by titration with SM 2320 B method; EC by a conductivity cell and pH by a potentiometric electrode (WTW Multi 9420). In all analyses charge-balance errors were $<10 \%$.

Information regarding stable isotopes $\left(\delta^{18} \mathrm{O}\right.$ and $\left.\delta^{2} \mathrm{H}\right)$ measurements (laboratories, techniques used and analytical errors) carried out in the 1999, 2000, 2007, 2010 and 2011 samplings can be found in Zabala et al. (2015). Creek samples from 2018 were analysed at the Isotope Hydrology Laboratory, Universidad Nacional de Mar del Plata (Argentina). Stable isotopes analysis was conducted using a water isotope analyser DLT-100 (Los Gatos Research Inc., USA). The analytical long-term uncertainty was: \pm 2.0 (\%) for $\delta^{2} \mathrm{H}$ and $\pm 0.3(\%)$ for $\delta^{18} \mathrm{O}$. Wetlands and groundwater samples from 2019 were analysed at the Stable Isotopes Research Group, Universidad Nacional (Heredia, Costa Rica). Those samples were filtered using a Midisart PTFE (polytetrafluorethylene) $0.45 \mu \mathrm{m}$ syringe membrane (Sartorius AG, Germany), transferred to $30 \mathrm{~mL}$ HDPE (high-density polyethylene) bottles and stored at $5{ }^{\circ} \mathrm{C}$ until analysis. Stable isotopes analysis was conducted using a water isotope analyser LWIA-45P (Los Gatos Research Inc., USA). The secondary standards were MTW $\left(\delta^{2} \mathrm{H}=-131.4 \%\right.$, $\delta{ }^{18} \mathrm{O}=-17.0 \%$ o $), 5 \mathrm{E}$ $\left(\delta^{2} \mathrm{H}=-9.26 \%\right.$, $\delta^{18} \mathrm{O}=-2.77 \%$ ), and CAS $\left(\delta^{2} \mathrm{H}=-64.3 \%\right.$, $\delta^{18} \mathrm{O}=$ $-8.3 \%$ o). MTW and 5E standards were used to normalize the results to the VSMOW-SLAP scale, while CAS was used as a quality control and drift control standard. The analytical long-term uncertainty was: \pm 0.5 $(\%)(1 \sigma)$ for $\delta^{2} \mathrm{H}$ and $\pm 0.1(\%)(1 \sigma)$ for $\delta^{18} \mathrm{O}$. Stable isotopes compositions are presented in delta notation $\delta$ (\%, per mil), relating the ratios (R) of ${ }^{18} \mathrm{O} /{ }^{16} \mathrm{O}$ and ${ }^{2} \mathrm{H} /{ }^{1} \mathrm{H}$ to Vienna Standard Mean Ocean Water (VSMOW). Deuterium excess was calculated as $d$-excess $=\delta^{2} \mathrm{H}-8 \cdot \delta^{18} \mathrm{O}$.

All data are available for download as electronic supplementary material from the Mendeley web site (Zabala et al., 2020) 10.17632/ b34kg4jx7r.1.

\section{Results}

4.1. Chemical and isotopic composition of precipitation water, surface water, and groundwater

Precipitation is the least mineralized water and its chemical composition varies within a narrow range, except for $\mathrm{pH}$ values, whereas groundwater is the most mineralized and its chemical composition varies widely (Fig. 4). The EC values of precipitation water ranged between 9 and $140 \mu \mathrm{S} / \mathrm{cm}$, in surface water ranged between 758 and $1462 \mu \mathrm{S} / \mathrm{cm}$, while in groundwater ranged between 686 and $6440 \mu \mathrm{S} /$ $\mathrm{cm}$. In the aquifer, salinity increased with depth. The most acidic and neutral $\mathrm{pH}$ values were measured in rainwater (4.70-7.89), while the most alkaline $\mathrm{pH}$ values were measured in wetlands (7.79-9.27). According to Glok Galli et al. (2011), the high pH values measured in Pampean surface waters may be linked to the decrease in the partial pressure of $\mathrm{CO}_{2}$ that occurs when groundwater discharges into creeks. Regarding alkalinity, higher and more scattered contents were measured in groundwater, mainly in shallow groundwater.

The weighted average chloride content in precipitation water for the entire basin was calculated as $1.3 \mathrm{mg} / \mathrm{L}$. The highest and most scattered contents of chloride and sulphate were measured in deep groundwater (11.1-902.4 mg/L and 9.5-1663.9 m/L, respectively), whereas shallow groundwater showed some outliers (2.2-541.6 $\mathrm{mg} / \mathrm{L}$ and $4.1-814.6 \mathrm{mg} / \mathrm{L}$, respectively). In wetland samples, the chloride content was higher and more scattered than in creek $(27.8-120.5 \mathrm{mg} / \mathrm{L}$, $10.9-104.3 \mathrm{mg} / \mathrm{L}$, respectively), while in creek the sulphate content is higher and more scattered than in wetland (creek: 13.5-284.6 mg/L; wetland: $11.1-104.3 \mathrm{mg} / \mathrm{L}$ ). Nitrate is the species with the greatest dispersion. The highest contents were measured in creeks and shallow groundwater $(30.1 \mathrm{mg} / \mathrm{L}$ and $33.2 \mathrm{mg} / \mathrm{L}$, respectively). On the other hand, deep groundwater showed the highest and most scattered sodium contents (126-1404 mg/L), while in surface water the range of variation was lower, mainly in wetlands (144-205 mg/L). The highest content of potassium was found in groundwater and wetlands and the lowest concentrations were found in the creeks. Calcium and magnesium contents were higher and more dispersed in groundwater than in surface water (Fig. 4).

Across the basin, the rainwater isotopic composition ranged between -9 and $-1.2 \%$ for $\delta^{18} \mathrm{O}$ and between -62 and $+11 \%$ for $\delta^{2} \mathrm{H}$. The average weighted values of $\delta^{18} \mathrm{O}$ and $\delta^{2} \mathrm{H}$ for each station were LG: -5.5 and $-31 \%$, IHLLA: -4.6 and $-25 \%$, LM: -5.2 and $-27 \%$, while $d$-excess values ranged between +4 and $+21 \%$. The creek $\delta^{18} \mathrm{O}$ and $\delta^{2} \mathrm{H}$ contents varied between $-5.5 \%$ and $-2.2 \%$ and between $-30 \%$ and $-17 \%$. Similarly, in wetlands $\delta^{18} \mathrm{O}$ and $\delta^{2} \mathrm{H}$ contents ranged between $-0.6 \%$ and $+10 \%$ and between $-6 \%$ and $+53 \%$. Notably, wetlands were more enriched than the creeks, showing a larger degree of kinetic fractionation. In the first $10 \mathrm{~m}$ depth of the aquifer, $\delta^{18} \mathrm{O}$ and $\delta^{2} \mathrm{H}$ compositions ranged from $-6.4 \%$ o to $-2.5 \%$ and from $-41 \%$ o to $-18 \%$ respectively, while at $30 \mathrm{~m}$ depth they ranged from $-5.7 \%$ o to $-4.2 \%$ and from $-35 \%$ o to $-23 \%$. In addition, the isotopic variations at $30 \mathrm{~m}$ depth were smaller than in the shallow depth.

\subsection{Local meteoric water line (LMWL)}

Fig. 5 shows the preliminary Local Meteoric Water Lines (LMWLs) calculated from biannual data (2011-2019) for the LG, IHLLA and LM stations (Fig. 5a, b and c), together with the Global Meteoric Water Line (GMWL) calculated by Craig (1961) and the Azul LMWL calculated by Dapeña et al. (2010), as references. A strong linear relationship exists between $\delta^{18} \mathrm{O}$ and $\delta^{2} \mathrm{H}$ biannual values across the three stations $\left(0.95<r^{2}>0.97\right)$. In the LG LWML the slope is $8.3 \pm 0.5$, while in the IHLLA LWML $(9.4 \pm 0.4)$ and LM LWML $(9.4 \pm 0.4)$ the slope values are higher. Similarly, the linear regression for LG exhibited a lower intercept $(16.2 \pm 3.0)$ when compared to IHLLA and LM intercepts $(21.2 \pm$ 2.3 and $23 \pm 2.9$, respectively). Overall, LMWLs in this region reflects the importance of moisture recycling (most likely by evapotranspiration) as expressed in relative large intercepts.

Given the similarity between the IHLLA (middle basin) and LM (lower basin) LMWLs, in the following analyses the LM LMWL will be used as representative of plain sectors in the basin, while the LG LMWL will be used to characterize the upper basin.

\subsection{Seasonal and spatial rainwater stable isotopes variation}

The weighted average isotopic values of rainwater in March-August (cold period) were similar in the middle and lower basins (IHLLA and LM), but they were significantly heavier than those measured in the 


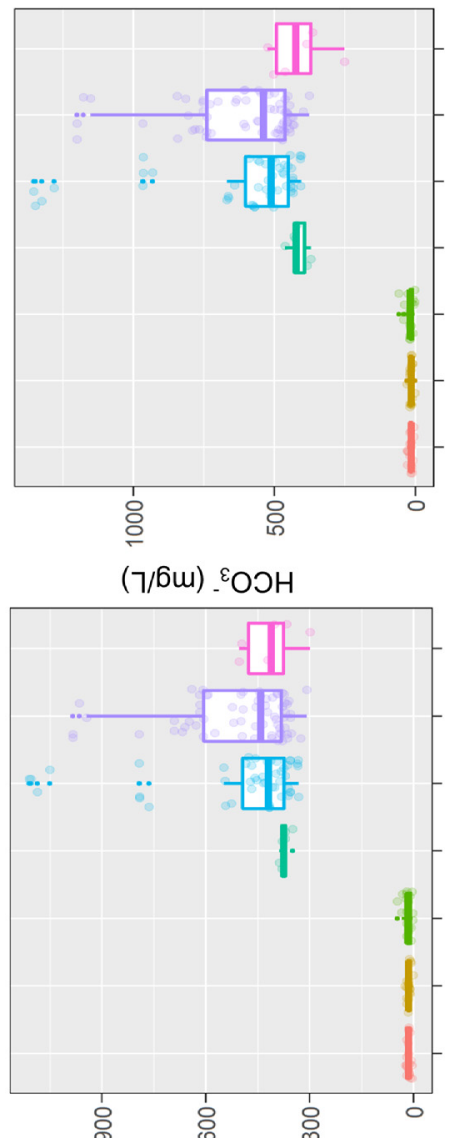

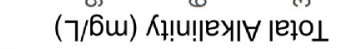

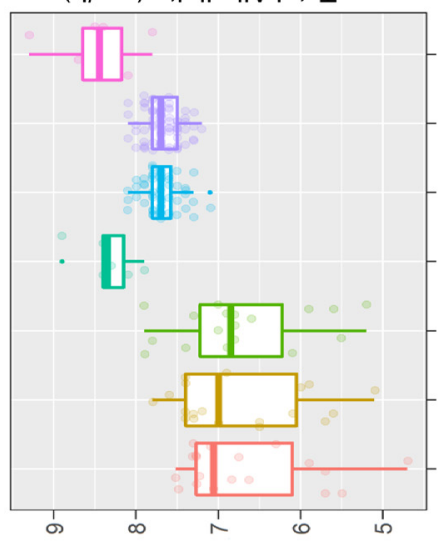

$\mathrm{H}^{\mathrm{d}}$

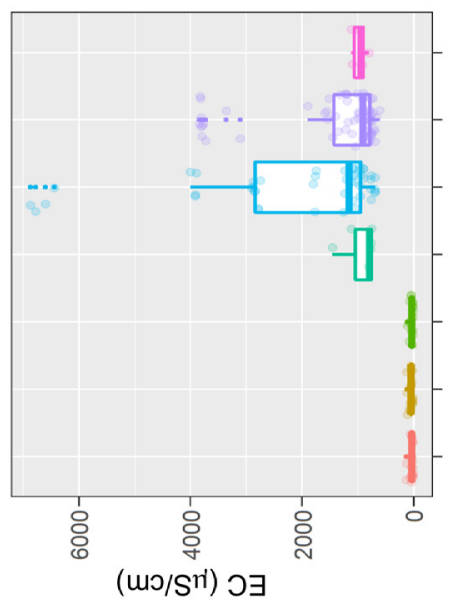

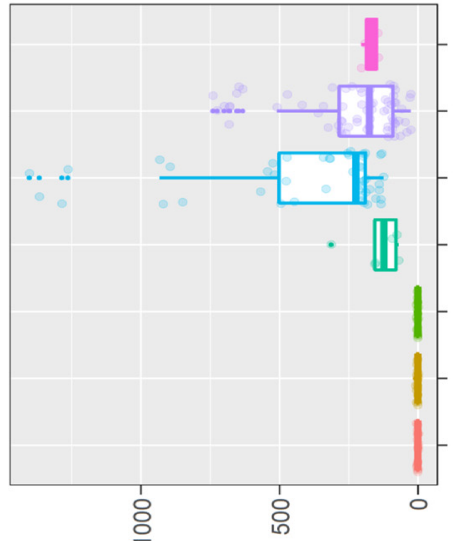

$(7 / 6 \mathrm{~m})_{+}^{+} \mathrm{eN}$

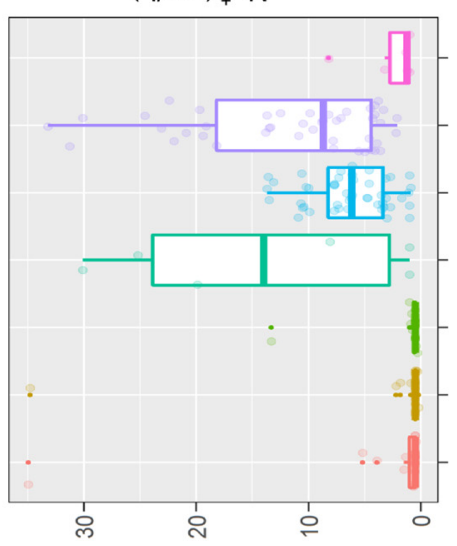

$(7 / 6 m)_{-}{ }^{\varepsilon} \mathrm{ON}$

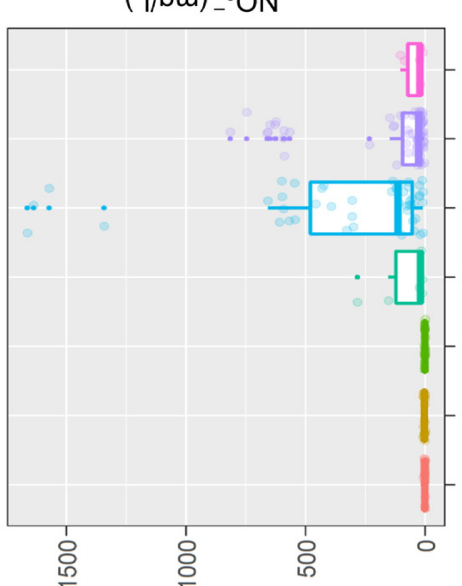

$(7 / 6 \bar{u})_{-2}^{\dagger} \mathrm{OS}$

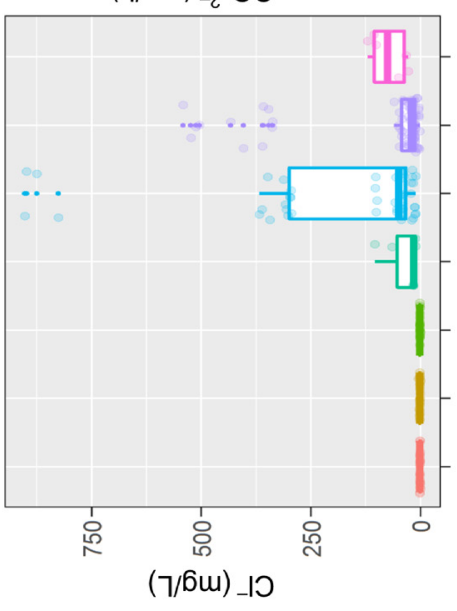

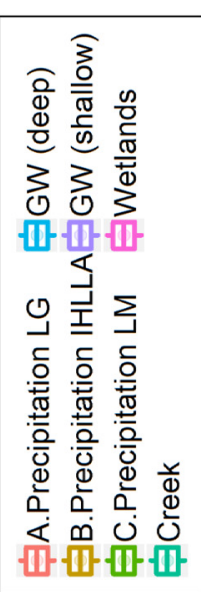
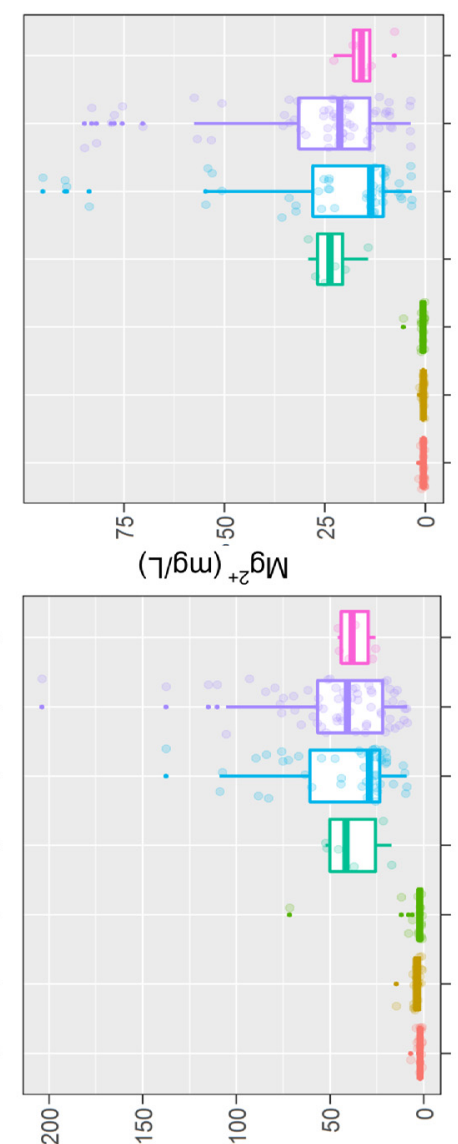

$(7 / 6 m)_{+2} e J$

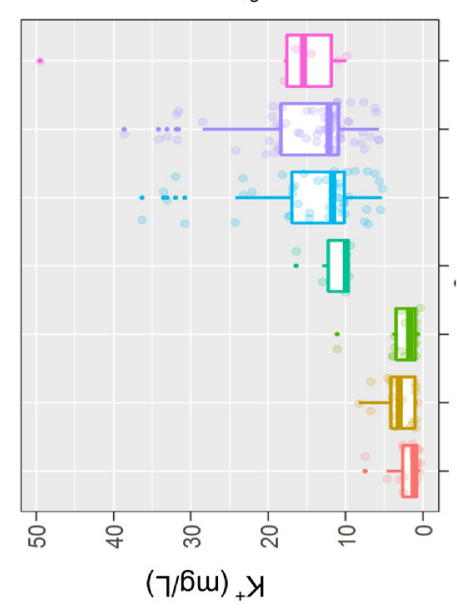




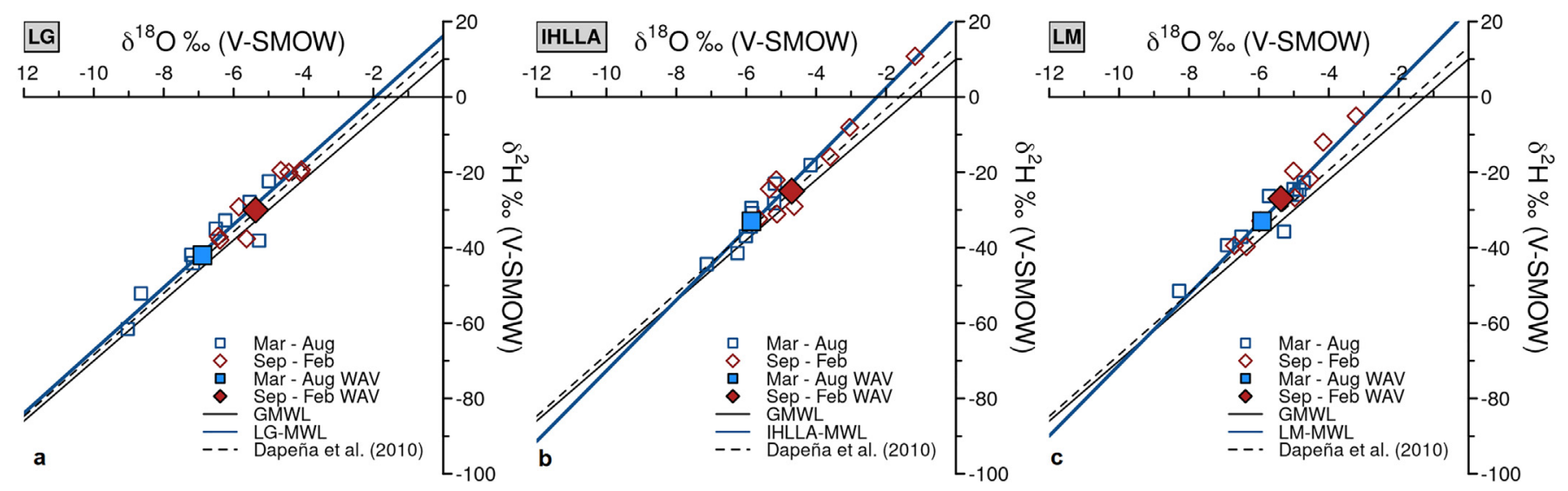

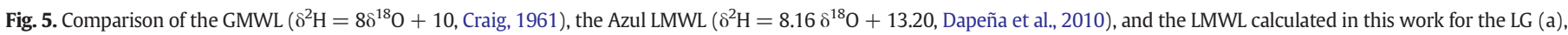
IHLLA (b), and LM (c) stations from biannual data (2011-2019). WAV = weighted average value.

upper basin (LG). However, the September-February values (warm period) were similar in the three stations, suggesting a rather homogenous origin of rainwater in the entire basin in this season (Fig. 5a, b, c). Nevertheless, the $d$-excess values did not change significantly across the basin for the March-August period (a value near $+14 \%$ o was observed at the three stations), while the values for the September-February period remained constant in the upper basin but were notably different in the middle and lower basins (IHLLA: 12\%。; LM: 16\%) (Fig. 6).

\subsection{Hydrological physical-processes}

\subsubsection{Evaporation}

Many water samples across the basin were strongly evaporated, more intensively surface water, but quite clearly and frequently, groundwater. Creek $d$-excess values ranged between +1 and $+13 \%$, while wetland $d$-excess values ranged between -27 and $-1 \%$. Deuterium excess values of creek samples from Site 3 and wetland samples are negatively correlated with $\delta^{18} \mathrm{O}$ contents, indicating that $d$-excess decreases as evaporation increases (Fig. 7). It is important to note that wetlands sampling was carried out in the spring season, and the isotopic compositions of these waters in summer is still unknown. Regarding groundwater, shallow groundwater $d$-excess values ranged between +1 and $+16 \%$, while at $30 \mathrm{~m}$ depth it ranged between +6 and $+16 \%$. At both depths the groundwater variation ranges were similar. A good number of shallow and deep samples had $d$-excess values significantly smaller than those of the precipitation in the basin, suggesting

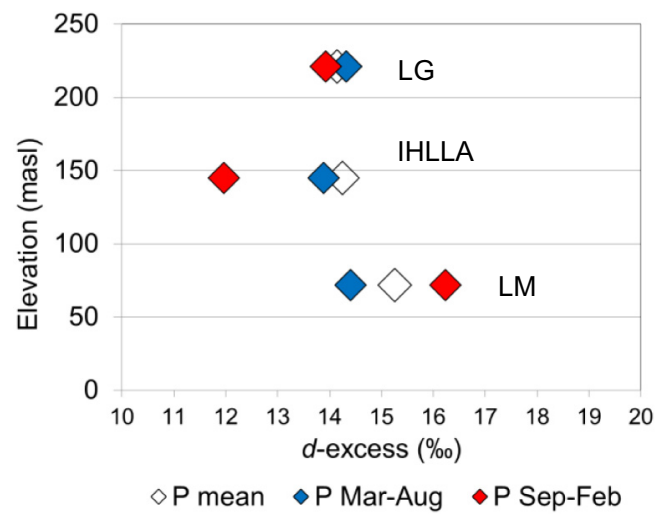

Fig. 6. Elevation vs. $d$-excess plot for rainwater. The March-August period represents the coldest seasons, while the September-February period represents the warmest seasons. fractionation by evaporation (Fig. 7). Some additional information on that process is described below.

Fig. 8a shows that creek samples from Sites 1 and 2 lie on the LG and LM LMWL, showing that in two contrasting hydrological situations (dry summer and humid spring) and in two different parts of the basin (upper and middle basin), surface water presents the same isotopic composition as the rainwater of the basin. However, creek samples from Site 3 (lower basin; summer and spring sampling) and all wetland samples (middle/lower basin; spring sampling) lie on an evaporation line (Fig. 8a). It is worth noting that wetlands are located along a SWNE direction, as both surface and groundwater flow lines (Fig. 1), hinting that they could be sites of surface water-groundwater interaction. These surface water bodies are hydrologically very dynamic and in dry periods many of them dry up completely. In the case of the W3, in the spring season it was practically dry, and the reason for sampling it was to characterize the surface water on this extreme hydrological stage. The Wetland Water Line (WWL) of these bodies can be described as: $\delta^{2} \mathrm{H}=5.50 \delta^{18} \mathrm{O} \pm 0.2-1.80 \pm 0.8\left(r^{2}: 0.99\right)$. The value of the WWL slope $(\mathrm{m}=5.5$ ), much lower than those of LMWLs in the DACB ( $\mathrm{m}$ in LG: $8.3 ; \mathrm{m}$ in IHLLA: 9.4; $\mathrm{m}$ in $\mathrm{LM}=9.4$ ). If the evaporation line is extended to the LWML, the isotopic composition before secondary evaporation results in a composition similar to rainfall samples and to non-evaporated shallow groundwater $\left(\delta^{18} \mathrm{O}:-5.40 ; \delta^{2} \mathrm{H}:-30 \%\right.$ o (Gibson et al., 2005).

Fig. 8b shows that both shallow groundwater and deep groundwater denoted a meteoric origin and they are mostly the result of local recharge. Moreover, the more disperse isotopic composition of shallow groundwater reflects a notable control of seasonal recharge, while the less variable isotopic composition of deep groundwater reflects the

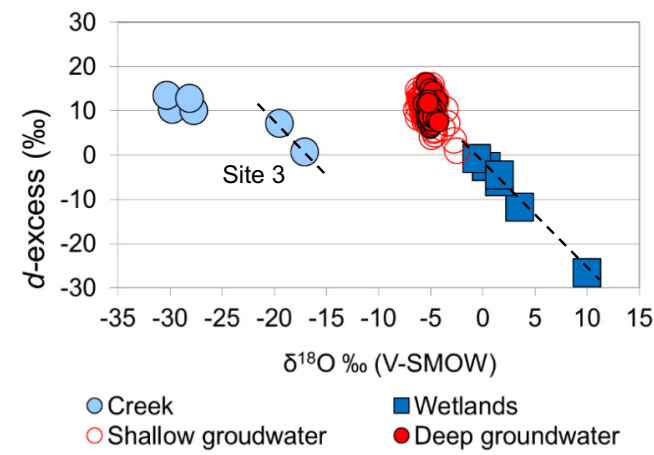

Fig. 7. Deuterium excess vs. $\delta^{18} \mathrm{O}$ plot for surface water (2018-2019) and groundwater (2018-2019) samples. 

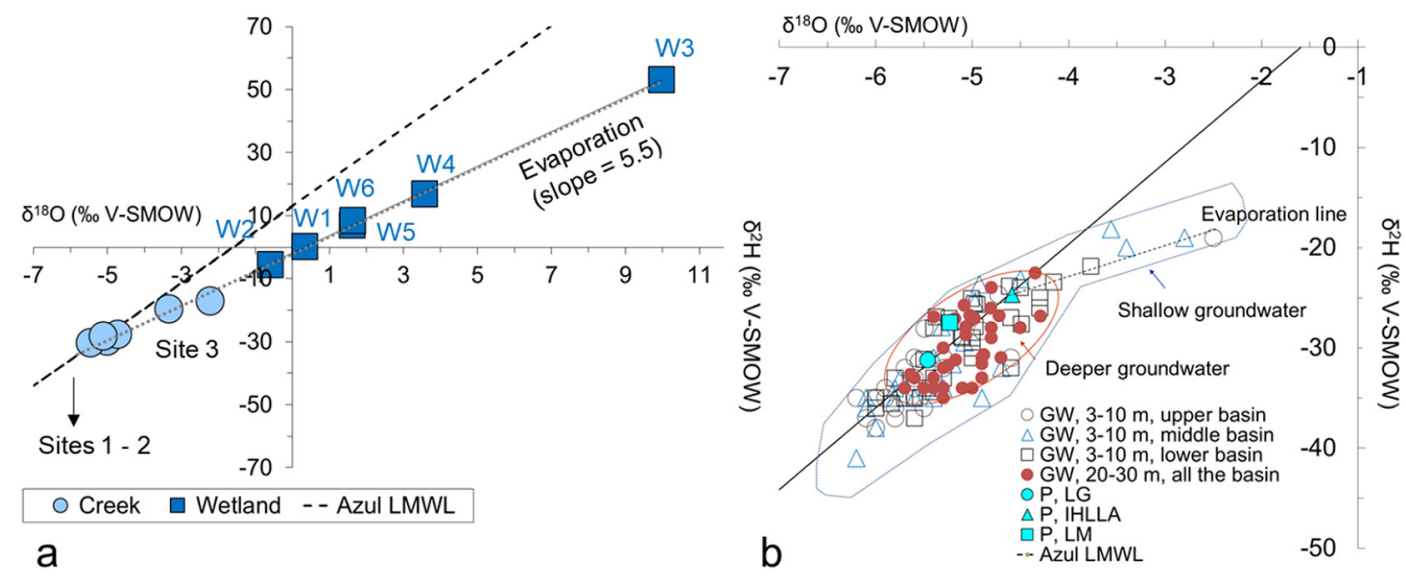

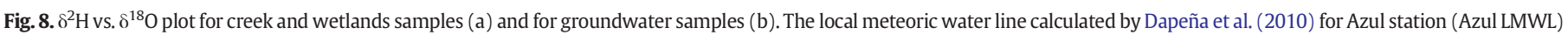
and the evaporation line for wetlands were drawn. W stands for wetland sites in Fig. 1 .

interannual average of the local precipitation, which means that at $30 \mathrm{~m}$ depth groundwater is a good mixture of interannual recharge. The figure also shows that many samples from both study depths, all located in the middle and lower basin, are evaporated (they lie well below the local meteoric water line), showing that evaporated groundwater is present at least as deep as $30 \mathrm{~m}$. However, the most enriched samples are only from the shallow depth and from sites in the lower basin, showing again a good interannual mixture at $30 \mathrm{~m}$. This increase in the groundwater isotopic enrichment from the middle to the lower basin was also observed in the chloride contents of groundwater (Zabala et al., 2015).

\subsubsection{Surface water and groundwater interaction}

As mentioned before, the groundwater salinity increases from SW to NE along the main flow direction (Fig. 9), and also increases with depth in the lower basin. The groundwater chemical types were similar in both sampling dates and depths, and temporal variations were not observed (Fig. 8). Shallow groundwater evolves from $\mathrm{CaMg}-\mathrm{HCO}_{3}$ type (P31, P32) to $\mathrm{Na}-\mathrm{Cl} / \mathrm{SO}_{4}$ (P12B), $\mathrm{Na}-\mathrm{HCO}_{3} / \mathrm{SO}_{4}$ (P5), and $\mathrm{Na}-\mathrm{SO}_{4} / \mathrm{Cl}$ (P7B) types in the lower basin. At $30 \mathrm{~m}$ depth, groundwater chemical types reproduce these of shallow groundwater. The chemical types evolve from Na-HCO $\mathrm{HCO}_{3}$ to $\mathrm{Na}-\mathrm{Cl}$ (I9), $\mathrm{Na}-\mathrm{HCO}_{3} / \mathrm{SO}_{4}$ (I13), and $\mathrm{Na}-\mathrm{SO}_{4} / \mathrm{Cl}$ $(\mathrm{I} 14, \mathrm{I12})$. A remarkable increase in the content of chloride and sulphate was observed towards the lower basin (Zabala et al., 2015).

In summer, when baseflow is dominant (Fig. 9 left), creek water evolves from $\mathrm{NaCa}-\mathrm{HCO}_{3}$ type in the upper and middle basin to $\mathrm{Na}$ $\mathrm{HCO}_{3} / \mathrm{SO}_{4}$ type in the lower basin. Moreover, the mineralization of the stream water and shallow groundwater are similar in the upper and middle basins, but in the lower basin the creek is less saline. The superficial flow rate values measured from Site 1 to Site 3 were $0.13,0.24$ and $0.49 \mathrm{~m}^{3} / \mathrm{s}$, respectively. In spring (Fig. 9 right), the chemical types of the creek were $\mathrm{NaCa}-\mathrm{HCO}_{3}$ in the upper and middle basins (Sites 1 and 2 ) and weakly $\mathrm{NaCa}-\mathrm{HCO}_{3} \mathrm{SO}_{4}$ in the lower basin (Site 3). The mineralization of the stream water was significantly smaller than that of shallow groundwater across the basin. The flow rate values measured from Site 1 to Site 3 were $0.17,1.9$ and $3.3 \mathrm{~m}^{3} / \mathrm{s}$, respectively. The 2018 summer was particularly dry, as shown by the low superficial flow values. In these conditions, evaporation is a relevant process in the control of the surface water chemistry, mainly in the flattest area, as evidenced by the isotopic composition presented in Fig. 8. In summer, creek water and groundwater compositions are quite similar. Taking into account the amount of precipitation, the superficial flow rates measured and the groundwater levels, the evidence indicates that the summer samples of the creek corresponded mostly to baseflow of shallow groundwater. On the other hand, in spring the measured superficial flows rates were considerably higher than those measured in summer, and the chemistry of the creek water was controlled by the mixture of precipitation water and groundwater, with dominance of the first source.

Regarding the interaction between wetlands and shallow groundwater, only chemical data for the spring season was available. Despite the fact that in spring the surface water bodies are fed both by groundwater and rainwater, the similarity of the chemical types of wetlands and groundwater ( $\mathrm{Na}-\mathrm{HCO}_{3}$ type) suggests that the aquifer discharges into wetlands and that mixing is a very relevant process (Fig. 10). In addition, samples $\mathrm{W} 3, \mathrm{~W} 4$, W5 and $\mathrm{W} 6$ (type $\mathrm{Na}-\mathrm{HCO}_{3} / \mathrm{Cl}$ ) have more chloride than samples W1 and W2. If we take into account that these samples are the most isotopically enriched, mainly W3 (Fig. 8), this increase can be attributed to concentration by evaporation. Thus, both mixing and evaporation play a major role in the control of the chemical composition of these surface water bodies.

\subsubsection{Isotopic changes from rainwater to groundwater}

In order to analyse whether the isotopic composition varies with depth during recharge and within the aquifer, the weighted average isotopic composition of rainwater from the three sampling stations was compared with the isotopic composition of groundwater samples taken in particular locations across the basin and at the two sampling depths (Fig. 11). According to Gat and Tzur (1967), in temperate climate areas the isotopic composition of groundwater is close to the average isotopic composition of rainwater in the recharge area. However, as shown in Fig. 8, in the DACB groundwater isotopic composition in the first $30 \mathrm{~m}$ depth of the Pampeano Aquifer shows modifications than can be attributed to evaporation and/or evapotranspiration. A more detailed assessment is presented here looking at samples from the different sectors of the basin.

Fig. 11 shows the weighted average composition of rainwater in the three rainfall stations for the whole analysed period, the weighted average composition of the September-February (warm seasons) and the March-August (cold seasons), and groundwater samples taken in warm and cold seasons at two sampling depths down to $30 \mathrm{~m}$ and in different locations across the basin. The figure clearly shows that the isotopic composition of shallow groundwater is notably influenced by the local seasonal recharge all across the basin, while at $30 \mathrm{~m}$ depth the seasonal variability is smoothed by mixing also across the basin.

This seems more evident in the upper basin (boreholes P27 and I2), where more significant differences exist between rainfalls from cold and warm seasons (Fig. 11). The latter may suggest that groundwater recharge takes place dominantly in spring and summer, as reported by Varni et al. (2013), and also that the shallow aquifer layers have a stronger connection to the active part of the water cycle.

In the upper and middle basin sectors, shallow groundwater samples from February 2007 (Fig. 11a and b) were somewhat lighter than the rest of the samples, which made them more similar to the March- 


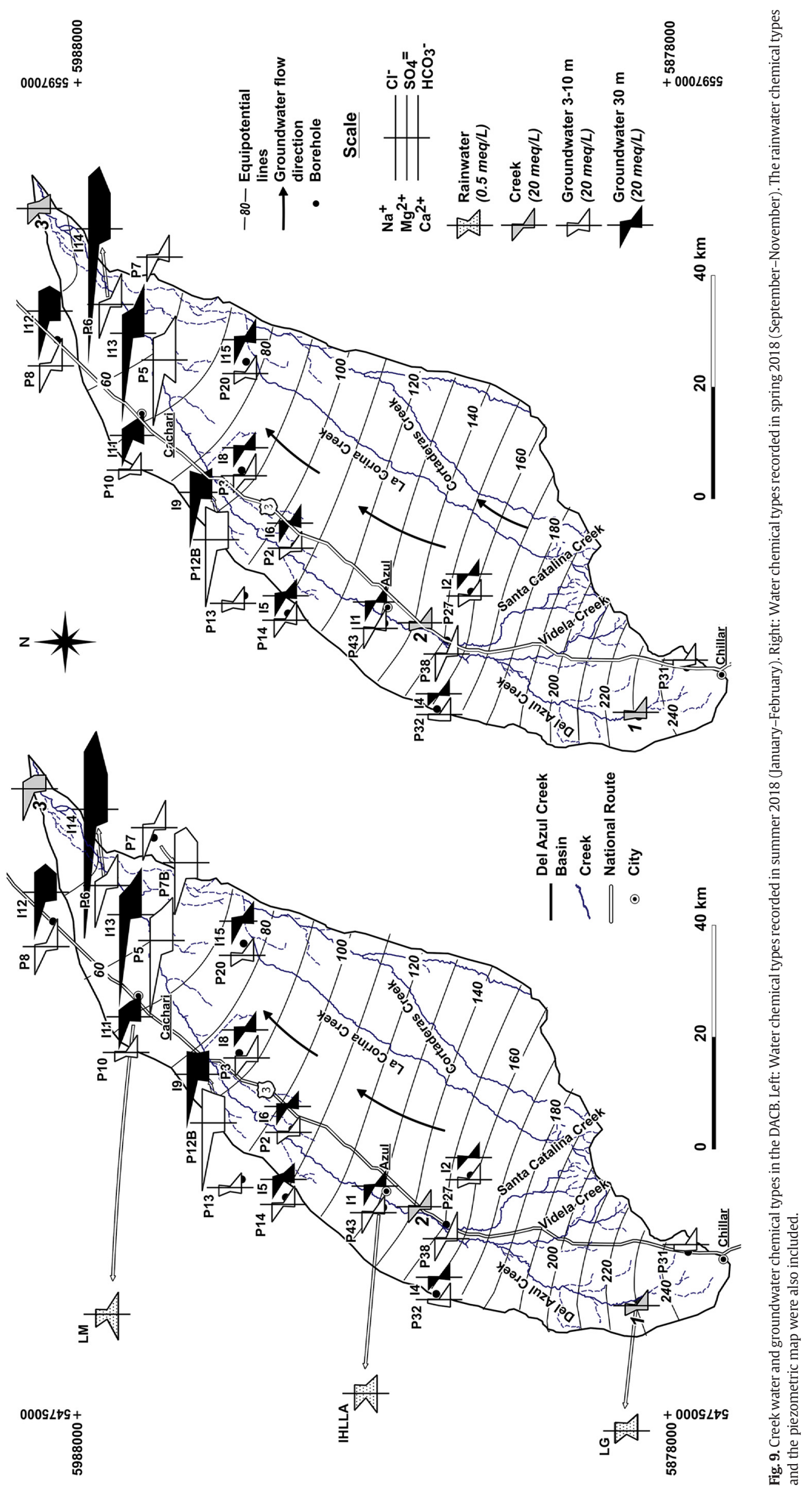




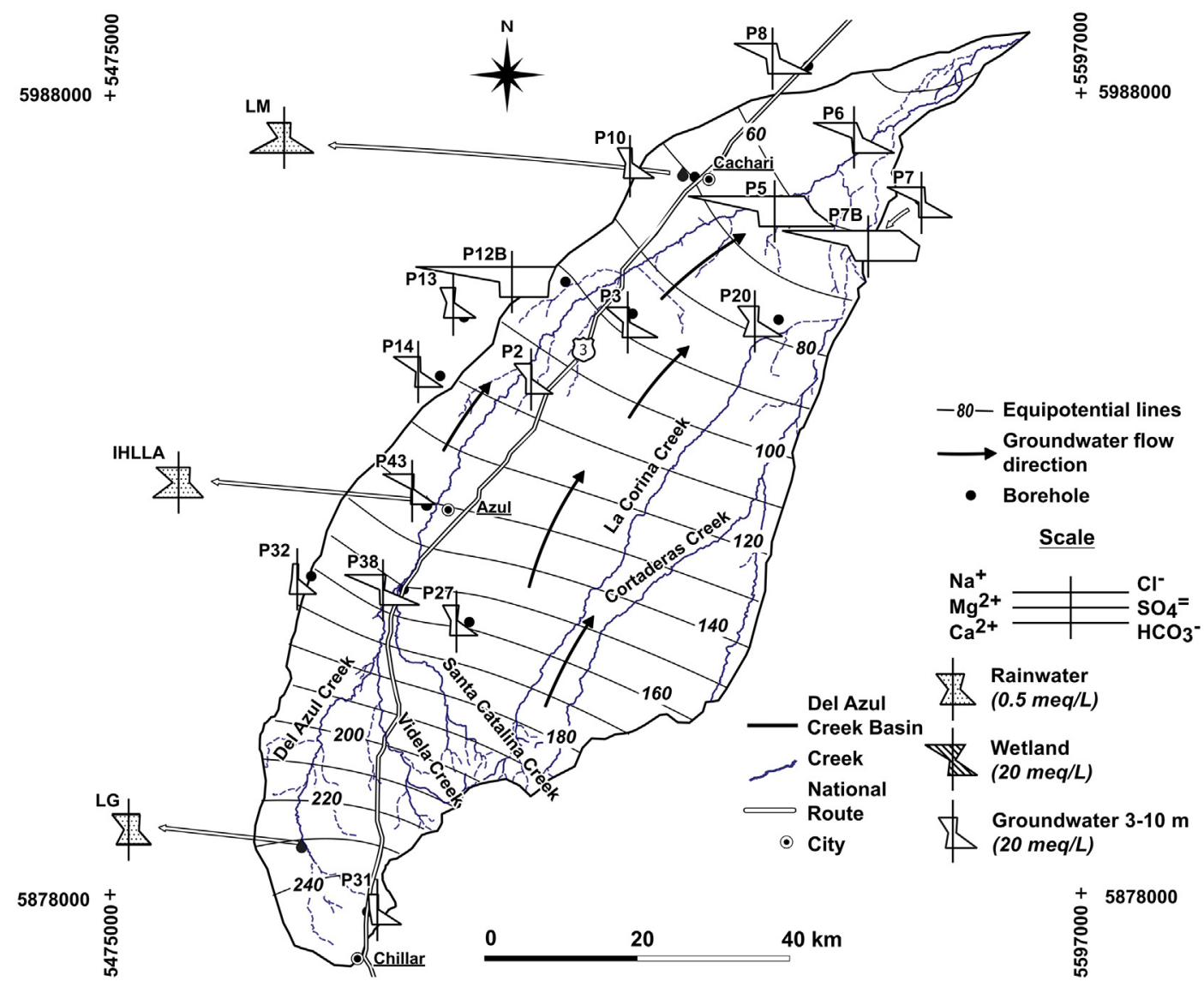

Fig. 10. Wetland and shallow groundwater chemical types in October 2019. The rainwater chemical types and the piezometric map were also included.

August precipitation. The rainfall recorded in February 2007 was particularly light, like other rainwater data reported for the same month by Dapeña et al. (2010). On the other hand, in the pair of boreholes P5-I13 (lower basin, Fig. 11d), shallow groundwater was evaporated probably before it reached the saturated zone, but samples taken at $30 \mathrm{~m}$ depth had constant composition along time and similar to the September-February rainfall from this area. In the pairs of boreholes P12B-I9 and P7-P7B (Fig. 11C and e), the latter being located in the flattest zone, the isotopic composition in both sites practically did not vary with depth and was very similar to the September-February rainfall.

In September 2019 a manual borehole was made to the $\mathrm{E}$ of the DACB, at the EMF site (Fig. 1). The water level was measured and a small water sample was taken to measure the EC value, and the contents of chloride and stable isotopes. These data (EM1) were compared with those measured in a $15 \mathrm{~m}$ depth borehole located at the same site (EMF2; screened between 9 and $14 \mathrm{~m}$ depth). The water table in both boreholes, EMF1 and EMF 2, was $1.23 \mathrm{~m}$ depth (Fig. 11f). The EC and chloride content values measured in EM1 were $1577 \mu \mathrm{S} / \mathrm{cm}$ and $83.9 \mathrm{mg} / \mathrm{L}$ respectively, while at 9-14 m depth they were $1653 \mu \mathrm{S} / \mathrm{cm}$ and $83.6 \mathrm{mg} / \mathrm{L}$. The isotopic contents in EMF1 were $\delta^{18} \mathrm{O}$ : $-5.2 \%$, $\delta^{2} \mathrm{H}:-30 \%$ and in EMF2 were $\delta^{18} \mathrm{O}$ : $-4.9 \%$, $\delta^{2} \mathrm{H}$ : $-29 \%$. Unfortunately there are not samples of other season from this place, but the similarity of the chemical and isotopic data measured at this site, together with the data of boreholes P12BI9 and P7-P7B, insinuate that in the lower basin the isotopic composition of shallow groundwater is less variable across the year, hence less controlled by the seasonal recharge and more controlled by the good mixing of interannual recharge (isotopically enriched by evaporation or/and evapotranspiration). All these observations have to be contrasted with repeated sampling.

\section{Discussion}

\subsection{Isotopic composition of water}

The hydrological processes developing in extensive plains differ considerably from those characterizing mountainous areas (Kovacs, 1978; Usunoff et al., 1999). The use of new tools, such as isotopic hydrology, and the multidisciplinary approach have made it possible to gain a better understanding of how hydrological processes work in these hydrological non-typical environments (McEwan et al., 2006). However, even today, large plains hydrology is a topic that still needs to be understood in greater detail. The DACB is part of one of the largest plains in the world, hence this work aims to contribute to unraveling the hydrological processes that occur in these environments.

On a regional scale, the results obtained here are in line with those obtained by several other authors. The DACB rainwater isotopic composition and the preliminaries LMWL (LG, IHLLA, LM) are in line with those contents and LMWL reported by Martínez et al. (2011). On the other hand, the surface water and groundwater are from meteoric origin and their isotopic compositions are in line with those reported by Glok Galli et al. (2011, 2018) for the Mar Chiquita and La Barrancosa lagoons, by Dapeña et al. (2001) for the Salado River basin, and by Quiroz Londoño et al. $(2008,2011,2015)$ for the El Moro, Tamangueyú and Seco streams basin and for the Quequén Grande River basin. Regarding evaporation, several authors state that evaporation produces characteristic heavy-isotope enrichment of surface waters, and that the slopes of the LMWL that have undergone evaporation range between 4 and 7 (Gonfiantini, 1986; Gat, 1996; Gibson et al., 2005). Relatively lower slopes indicate evaporative enrichment and a strong kinetic influence on the evaporation process (Craig, 1961). In the DACB, the slope of the wetlands line is 5.5 and is similar to that calculated by Glok Galli et al. 


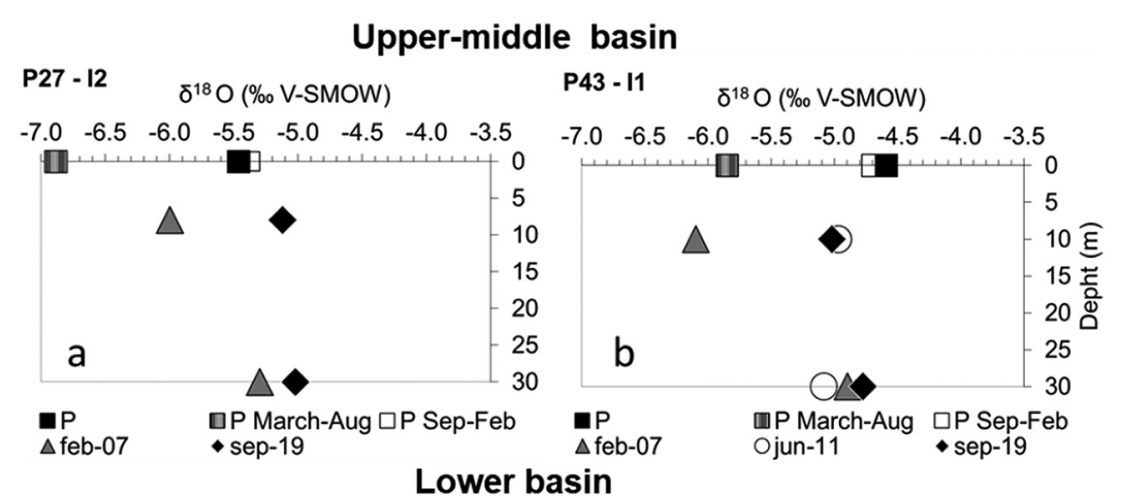

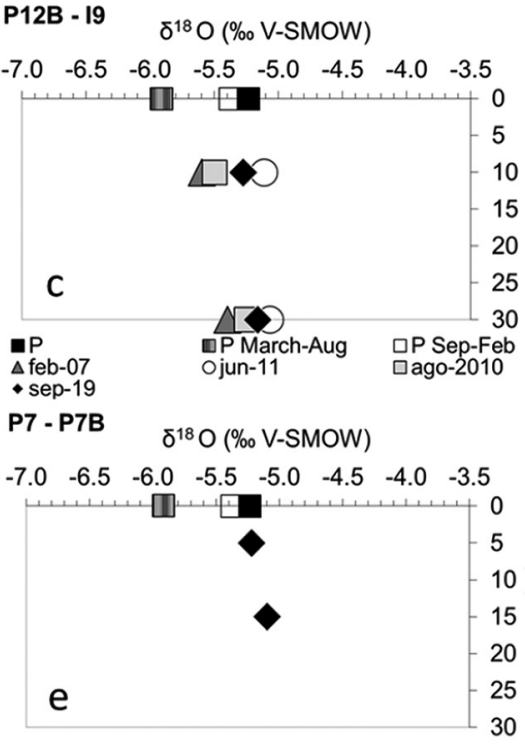

口P $\square$ P March-Aug $\square$ P Sep-Feb $\bullet$ sep-19

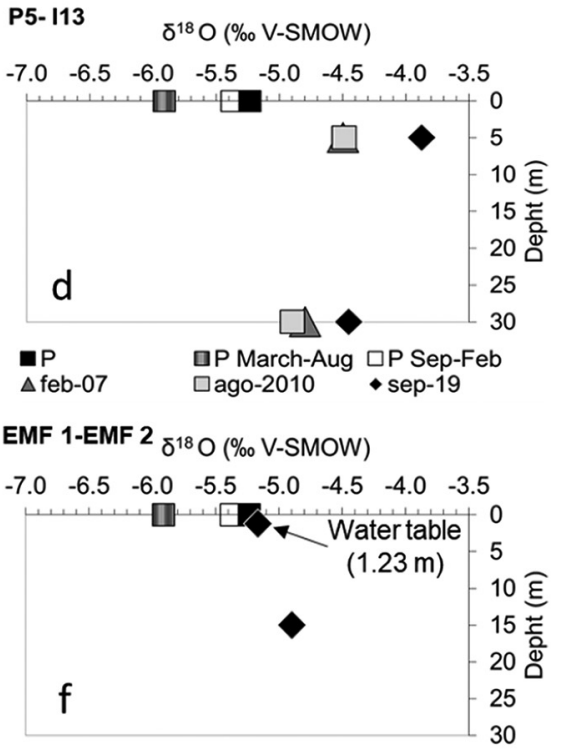

- $\mathrm{P}$ 口 $\mathrm{P}$ March-Aug $\square \mathrm{P}$ Sep-Feb $\downarrow$ sep-19

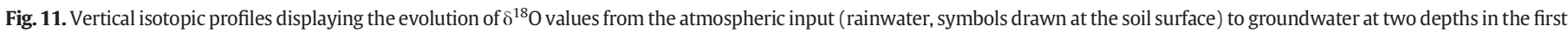

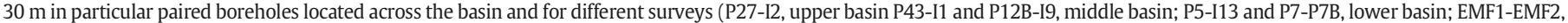
outside and E of the lower basin). P: weighted average composition of the precipitation in the whole sampled period; P March-Aug and P Sept-Feb: idem in the indicated months.

(2011 and 2018) for the Mar Chiquita Lagoon $(m=5.5)$ and for the La Barrancosa Lagoon $(m=5)$. In the Salado River basin the slope value calculated was 5.7 (Dapeña and Panarello, 2004). Carol et al. (2009) reported a slope value of 4.9 for the coastal plain, whereas Quiroz Londoño et al. (2008) for the Tamangueyú, El Moro and Seco streams reported a slope value of 5.7 .

\subsection{Hydrological conceptual model}

The DACB is $150 \mathrm{~km}$ long and $20-60 \mathrm{~km}$ wide. Height differences range between 350 and 30 masl. Across the basin, the isotopic composition of rainfall varies more or less significantly in time and space (Fig. 12). The lightest rainfalls occur during the coldest seasons, while the heaviest ones occur during the warmest seasons. At the same time, in cold seasons the lightest rainwater of the basin falls in the upper basin, while in the middle and lower basins rainfall is somewhat heavier and similar to each other. In warm seasons, the isotopic composition of rainfall is similar across the entire basin, except in the middle basin where the isotopic content is slightly heavier. On the other hand, in the entire basin the atmospheric vapor comes mainly from recycled moisture.

In the $\mathrm{DACB}$, the evaporation process begins to be relevant in the flattest sector of the basin, where groundwater is practically emerging and where groundwater discharge into creeks and wetlands is larger. Here water moves slowly due to the low ground slopes, favoring the occurrence of evaporation. The most evaporated waters are the superficial ones, mainly those from the wetlands ( $d$-excess $=-27$ to $-1 \%$ ). According to this physical process, the basin can be divided into two parts: 1) The upper and middle basin, where even during two contrasting hydrological periods (dry summer and humid spring) neither surface nor groundwater was evaporated (waters presented similar isotopic compositions and in turn reflected strongly their meteoric origin); 2) the middle and lower basins, where mainly during the warmest seasons, surface waters and some groundwaters are isotopically enriched.

Aquifer discharge into creeks increases from upper to lower basins and from summer to spring. In the lower basin superficial flow rates increased from 0.49 to $3.29 \mathrm{~m}^{3} / \mathrm{s}$. Therefore, in the flattest sector surface water-groundwater interaction is a key hydrological process. This statement is supported by the water chemical composition. In summer (dry season) the chemistry of creeks water is similar to shallow groundwater across the basin, evidencing the contribution of groundwater to baseflow. In spring (humid season), creek water is chemically similar to shallow groundwater in the upper and middle basins, but in the lower basin it is less saline, most probably due to dilution by precipitation. Therefore, groundwater-surface water interaction and the consequent mixing of water seem relevant processes across the year. In the case of wetlands, as the water chemical types reveal, the interaction between surface water and groundwater plays a key role. In spring, wetlands chemical types are similar to those of shallow groundwater, suggesting groundwater contribution. The chemistry of surface water bodies is controlled by mixing but also, as indicated by the isotopic 


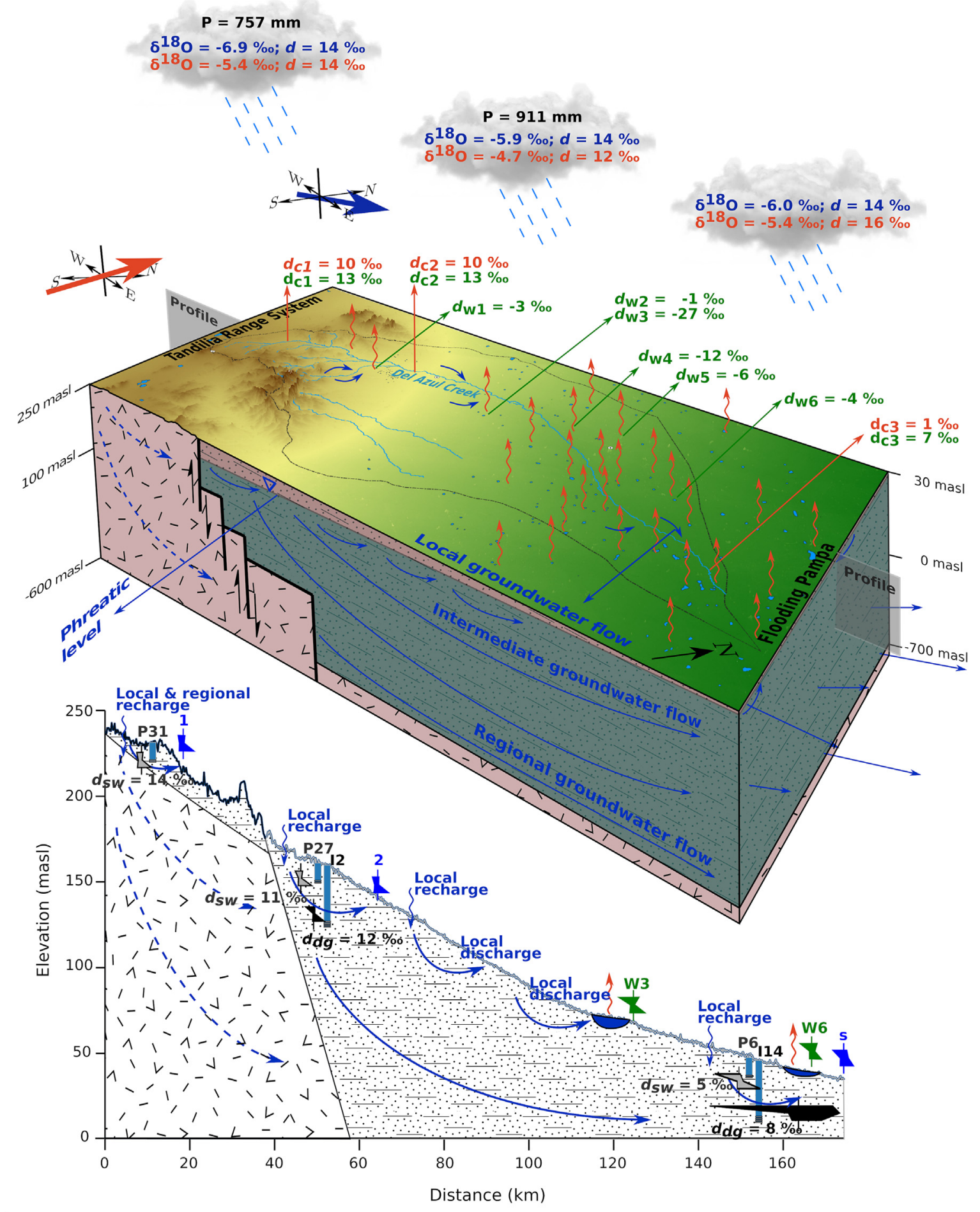

\section{Explanation}

$\mathrm{P}=$ average annual rainfall

$\delta^{18} \mathrm{O}=$ March - August weighted average contents

$\delta^{18} \mathrm{O}=$ September - February weighted average contents

$\longrightarrow$ Direction of rainfall increase in March - August

Direction of rainfall increase in September - February

$d_{\mathrm{c} 1}=d$-excess creek (summer) - Site 1

$20 \quad 0 \quad 20 \mathrm{meq} / \mathrm{L}$

$d_{\mathrm{c} 1}=d$-excess creek (spring) - Site 1

$d_{\mathrm{w} 1}=d$-excess wetland (spring) - Site 1

$d_{\mathrm{sw}}=d$-excess shallow groundwater (spring)

$d_{\mathrm{dg}}=d$-excess deep groundwater (spring)

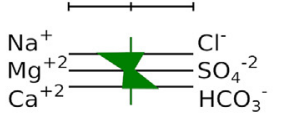

Digital Elevation model

30 masl

350 masl 
data, by the occurrence of evaporation, in addition to other chemical processes. The shallow depth of these water bodies enhances evaporation, which results in isotopic enrichment of their water.

During groundwater recharge, the isotopic composition of water changes more or less notably all across the basin. In general, shallow groundwater (which in most of the boreholes is not the water at the water table, but somewhat deeper) shows some isotopic enrichment with respect to the local precipitation regardless of their location in the basin, though this is not observed in all the boreholes. The shallower groundwater samples show a fractionation range wider than the deeper ones. Thus, the composition of most shallow groundwater reflects dominantly that of the seasonal recharge modified -isotopically enriched- by evaporation in different degrees, while the composition of the deep groundwater reflects dominantly the weighted composition of interannual recharge. Evaporative fractionation of water could occur during the warm season both in the atmosphere, affecting air moisture and falling rain drops (Araguas-Araguas et al., 2000; Salamalikis et al., 2016), in the soil surface (ponds, lagoons, rivers; Craig and Gordon, 1965; Kyounghee and Xuhui, 2011), and also during and after recharge, induced by the physical process of evapotranspiration (Gat, 1981). This aspect has not yet been addressed in the DACB.

In spite of the observed control of seasonal recharge, in general the isotopic composition of shallow groundwater resembles more that of the rainfall period from September to February (warm seasons), suggesting that recharge occurs mostly during this period. This statement is in line with what was observed by Varni et al. (2013) from the use of other tools. If groundwater reflects the isotopic composition of spring-summer rainfalls, thus the maximum recharge is achieved during these warmest seasons and recharge occurs soon after rainfall. In addition, although the shallower part of the first $30 \mathrm{~m}$ of aquifer has an active flow and is connected to streams and wetlands, and in the deeper part the flow velocity is slow enough as to allow mixing of interannual recharge, both parts are hydraulically well connected, as denotes the influence of the chemical and isotopic composition of shallow groundwater in groundwater at $30 \mathrm{~m}$ depth.

\section{Conclusions}

The isotopic composition of rainfall revealed seasonal variations across the basin. The lightest rainfalls occurred during the coldest seasons, while the heaviest ones occurred during the warmest seasons. Isotopic spatial variation is only observed during the cold period. At this time, the lightest rainfalls were produced in the upper basin, while in the rest of the basin and during the warmer seasons, no differences were observed between the upper and lower basins. Regarding the origin of the atmospheric water vapor, the $d$-excess values point out that it comes mainly from recycled moisture. This new information will be very useful for planning the new location of the collectors and the sampling frequency, in order to understand what the controls on the rainwater isotopic contents are in this basin and how and why they vary in space and time. In our future works we are planning to include the heterogeneity of rainfall in our analyses and also to study the sources of moisture.

Evaporation plays a key role in the flattest basin sector, mainly during the warmest seasons (spring and summer). The Wetland Water Line for the basin is calculated as $\delta^{2} \mathrm{H}=5.50 \cdot \delta^{18} \mathrm{O} \pm 0.2-1.80 \pm 0.8$. On the other hand, the interaction between groundwater and surface water is another important hydrologic process that controls the quantity, chemical composition and quality of water. Aquifer discharge increases from upper to lower basin, and from summer to spring, as chemical types and superficial flow values indicated.

The isotopic composition of shallow groundwater reflects the local seasonal recharge, while the isotopic composition of deep groundwater reflects the weighted composition of interannual recharge. In addition, groundwater reflects the isotopic composition of rainfall from springsummer (September-February), which indicates that the maximum recharge is achieved during these warmer seasons, recharge occurs soon after rainfalls, and the aquifer is hydraulically well connected (at least in the first $30 \mathrm{~m}$ of depth). Despite this good connection, the shallowest groundwater integrates the most active part of the hydrological cycle, which is reflected in the isotopic composition variability.

This study provides direct evidence showing that evaporation and the interaction between groundwater and surface water play a key role in the control of the isotopic and chemical composition of water. Given the importance of these processes in the control of water quantity and quality in the most productive region of Argentina, it is deemed necessary to quantify them in order to adjust the basin hydrological balance. Understanding the dynamics of water is essential to safeguard the sustainable management of water resources.

\section{CRediT authorship contribution statement}

M.E. Zabala: Conceptualization, Methodology, Formal analysis, Investigation, Writing - original draft, Visualization, Supervision, Project administration, Funding acquisition. M. Gorocito: Formal analysis, Investigation, Writing - review \& editing, Visualization. S. Dietrich: Conceptualization, Methodology, Formal analysis, Resources, Writing review \& editing, Visualization. M. Varni: Conceptualization, Writing review \& editing. R. Sánchez Murillo: Formal analysis, Resources, Writing - review \& editing, Visualization. M. Manzano: Conceptualization, Writing - review \& editing. E. Ceballos: Writing - review \& editing.

\section{Declaration of competing interest}

The authors declare that they have no known competing financial interests or personal relationships that could have appeared to influence the work reported in this paper.

\section{Acknowledgements}

This research was supported by the Instituto de Hidrología de Llanuras "Dr. Eduardo J. Usunoff" (IHLLA, Argentina) and the project PICT 2016 No. 3688. The first, third and seventh authors are funded by the Consejo Nacional de Investigaciones Científicas y Técnicas (CONICET, Argentina), while the second author is funded by the Agencia Nacional de Promoción Científica y Tecnológica (ANPCyT, Argentina). We thank the IHLLA technical staff Enrique Queupán, Joaquín Rodríguez María Fátima Altolaguirre, Ornella Floriani and Georgina Cazenave, for their assistance in carrying out the water sampling, the chemical analyses and the superficial flow rate measurements. Special thanks to Mariana Oyarzabal for English assistance to Martín Mazza for the images of the graphical abstract. The authors welcome comments from anonymous reviewers, whose observations have been very helpful improving the manuscript.

\section{References}

APHA, 2012. Standard Methods for the Examination of Water and Wastewater. American Public Health Association, Washington.

Araguas-Araguas, L., Froehlich, K., Rozanski, R., 2000. Deuterium and oxygen-18 isotope composition of precipitation and atmospheric moisture. Hydrol. Process. 14, 1341-1355.

Armengol, S., Manzano, M., Bea, S., Martínez, S., 2017. Identifying and quantifying geochemical and mixing processes in the Matanza-Riachuelo Aquifer System, Argentina. Sci. Total Environ. 599-600, 1417-1432. https://doi.org/10.1016/j. scitotenv.2017.05.046.

Bahir, M., Ouazar, D., Ouhamdouch, S., 2019. Hydrogeochemical mechanisms and recharge mode of the aquifers under semiarid climate from Morocco. Appl Water Sci 9, 103. https://doi.org/10.1007/s13201-019-0988-7.

Bajjali, W., 2006. Recharge mechanism and hydrochemistry evaluation of groundwater in the Nuaimeh area, Jordan, using environmental isotope techniques. Hydrogeol. J. 14 (1), 180-191. https://doi.org/10.1007/s10040-004-0352-2.

Barberá, J.A., Jódar, J., Custodio, E., González-Ramón, A., Jiménez-Gavilán, P., Vadillo, I., Pedrera, A., Martos-Rosillo, S., 2018. Groundwater dynamics in a hydrologicallymodified alpine watershed from an ancient managed recharge system (Sierra Nevada 
National Park, Southern Spain): insights from hydrogeochemical and isotopic information. Sci. Total Environ. 640-64, 1874-1893. https://doi.org/10.1016/j. scitotenv.2018.05.305

Barros, V., Perczyk, D., 2006. República Argentina: Vulnerabilidad a Cambios Climáticos e Hidrológicos, Secretaría de Ambiente y Desarrollo Sustentable e Instituto Torcuato Di Tella. p. 390.

Bershaw, J., Lechler, A., 2019. The isotopic composition of meteoric water along altitudinal transects in the Tian Shan of Central Asia. Chem. Geol. 516, 68-78.

Boukhari, K., Fakir, Y., Stigter, T., Hajhouji, Y., Boulet, G., 2014. Origin of recharge and salinity and their role on management issues of a large alluvial aquifer system in the semi-arid Haouz plain, Morocco. Environ. Earth Sci. https://doi.org/10.1007/s12665014-3844-y.

Carol, E., Kruse, E., Mas-Pla, J., 2009. Hydrochemical and isotopical evidence of ground water salinization processes on the coastal plain of Samborombón Bay, Argentina. J. Hydrol. 365, 335-345.

Carretero, S., Dapeña, C., Kruse, E., 2011. Caracterización isotópica de las aguas subterráneas en el norte del Partido de la Costa, provincia de Buenos Aires. Proceedings XVIII Congreso Geológico Argentino, Geología: Un puente entre la Naturaleza y el Hombre, Neuquén, Argentina.

Carretero, S., Dapeña, C., Kruse, E., 2013. Hydrogeochemical and isotopic characterisation of groundwater in a sand-dune phreatic aquifer on the northeastern coast of the province of Buenos Aires, Argentina. Isot. Environ. Health Stud. 49, 399-419.

Cazenave, G., Vives, L., 2014. Predicción de inundaciones y sistemas de alerta: Avances usando datos a tiempo real en la cuenca del arroyo del Azul. Revista de Geología Aplicada a la Ingeniería y al Ambiente 33 (83-91).

Consejo Nacional de Coordinación de Políticas Sociales (CNCPS), 2019. Informe Objetivos de Desarrollo Sostenible Provincias. Technical report. 293 p. Available from. https:// www.odsargentina.gob.ar/public/documentos/seccion_publicaciones/provmuni/ informe_provincias_ods_2016-19.pdf. (Accessed 25 May 2020).

Craig, H., 1961. Standard for reporting concentrations of deuterium and oxygen-18 in natural waters. Science 133 (3467), 1833-1834.

Craig, H., Gordon, L.I., 1965. Deuterium and oxygen 18 variations in the ocean and the marine atmosphere. In: Tongiorgi, E. (Ed.), Stable Isotopes in Oceanographic Studies and Paleotemperatures, Lischi and Figli, Pisa, Italy (1965), pp. 9-130.

Dapeña, C., Panarello, H.O., 1999. Development of the National Network for Isotopes in Precipitation of Argentina. Proceedings II South American Symposium on Isotope Geology. pp. 503-508.

Dapeña, C., Panarello, H., 2004. Composición isotópica de la lluvia de buenos aires. Su importancia para el estudio de los sistemas hidrológicos pampeanos. Revista Latino-Americana de Hidrogeología 4, 17-25.

Dapeña, C., Miretzky, P., Panarello, H., FernándezCirelli, A., 2001. Environmental stable isotope of the 'Sistema de las Encadenadas de Chascomús', Buenos Aires, Argentina. Proceedings III South American Symposium on Isotope Geology, Chile.

Dapeña, C., Varni, M., Panarello, H.O., Ducos, E., Weinzettel, P., Usunoff, E., 2010. Composición isotópica de la precipitación de la Estación Azul, provincia de Buenos Aires. Red Nacional de Colectores Argentina. In: Varni, M., Entraigas, I., Vives, L. (Eds.), Hacia la Gestión Integral de los Recursos Hídricos en Zonas de Llanura. Editorial Martín, Mar del Plata, pp. 386-393.

Dietrich, S., Carrera, J., Weinzettel, P., Sierra, L., 2018. Estimation of specific yield and its variability by electrical resistivity tomography. Water Resour. Res. 54. https://doi. org/10.1029/2018WR022938.

Dogramaci, S., Skrzypek, G., Dodson, W., Grierson, P., 2012. Stable isotope and hydrochemical evolution of groundwater in the semi-arid Hamersley Basin of subtropical northwest Australia. J. Hydrol. 475, 281-293. https://doi.org/10.1016/j. jhydrol.2012.10.004.

Entraigas, I., Varni, M., Gandini, M., Usunoff, E., Vázquez, P., 2004. Inundación y Anegamiento. In: Bejerman, N.J., Gonzáles, M.A. (Eds.), Peligrosidad Geológica en Argentina. Metodologías de Análisis y mapeo. Estudio de casos. Editorial Asociación Argentina de Geología Aplicada a la Ingeniería, Córdoba, pp. 230-246.

Entraigas, I., Vercelli, N., Ares, M., Varni, M., Zeme, S., 2017. Flooding effects on grassland species composition in the Azul creek basin, Argentina. Rangeland J. 39, 245-252.

Farid, I., Zouari, K., Trabelsi, R., RahmenKallali, A., 2014. Application of environmental tracers to study groundwater recharge in a semi-arid area of Central Tunisia. Hydrol. Sci. J. 59 (11), 2072-2085. https://doi.org/10.1080/02626667.2013.863424.

Fidalgo, F., Riggi, J.C., Gentile, R., Correa, H., Porro, N., 1991. Los "Sedimentos Postpampeanos" continentales en el ámbito sur bonaerense. Rev. Asoc. Geol. Argent. 46, 239-256.

Gat, J.R., 1981. Properties of the isotopic species of water: the "isotope effect”. In: Gat, J.R., Gonfiantini, R. (Eds.), Stable Isotope Hydrology, Deuterium and Oxygen-18 in the Water Cycle, IAEA Tech. Rep. Ser. No. 210. IAEA, Vienna, pp. 7-19.

Gat, J., 1996. Oxygen and hydrogen isotopes in the hydrologic cycle. Annu. Rev. Earth Planet. Sci. 24, 225-262.

Gat, J., Tzur, Y., 1967. Modification of the isotopic composition of rainwater by processes which occur before groundwater recharge. Proceedings Isotopes in Hydrology, Vienna, pp. 49-60.

Gibson, J., Edwards, T., Birks, S., St Amour, N., Buhay, W., McEachern, P., Peters, D., 2005. Progress in isotope tracer hydrology in Canada. Hydrol. Process. J. 19, 303-327.

Glok Galli, M., Martínez, D., Kruse, E., Lima, L., Grondona, S., 2011. Caracterización hidrogeoquímica e isotópica de las nacientes de la Cuenca de la laguna Mar Chiquita, provincia de Buenos Aires. Proceedings VII Congreso Argentino de Hidrogeología y V Seminario Hispano-Latinoamericano Sobre Temas Actuales de la Hidrología Subterránea. Calidad y Contaminación de Agua Subterránea. Salta, Argentina, pp. 76-83.

Glok Galli, M., Colasurdo, V., Martínez, D., Grosman, F., Quiroz Londoño, M., Salzano, P., 2018. Caracterización hidrogeoquímica e isotópica de La Laguna la Barrancosa (Provincia De Buenos Aires) y su interacción con el acuífero Pampeano. Proceedings
X Congreso Argentino y XIV Congreso Latinoamericano de Hidrogeología. Química, Calidad y Contaminación del Agua. Salta, Argentina, pp. 131-138.

Gonfiantini, R., 1986. Environmental isotopes in lake studies. In: Fritz, P., Fontes, J.Ch. (Eds.), Handbook of Environmental Isotopes Geochemistry. vol. 2, pp. 113-168.

Gonzales Amaya, A., Barmen, G., Muñoz, G., 2018. A multidisciplinary approach for clarifying the recharge processes and origin of saline water in the semi-arid Punata alluvial fan in Bolivia. Water 10, 946. https://doi.org/10.3390/w10070946.

Guevara Ochoa, C., Median Sierra, A., Vives, L., Zimmermann, E., Bailey, R., 2019. Spatiotemporal patterns of the interaction between groundwater and surface water in plains. Hydrol. Process. 34, 1371-1392. https://doi.org/10.1002/hyp.13615.

Hoke, G., Aranibar, J., Viale, M., Araneo, D., Llano, C., 2013. Seasonal moisture sources and the isotopic composition of precipitation, rivers, and carbonates across the Andes at 32.5-35.5ㅇ. Am. Geophys. Union 14, 4. https://doi.org/10.1002/ggge.20045.

INDEC- Instituto Nacional de Estadística y Censos, 2010. Censo Nacional de Población Hogares y Viviendas. Available from. https://www.indec.gob.ar/indec/web/Nivel4CensoNacional-3-999-Censo-2010. (Accessed 25 May 2020).

Jódar, J., Custodio, E., Lambán, J.L., Martos-Rosillo, S., Herrera, C., Sapriza, G., 2016. Vertical variation in the amplitude of the seasonal isotopic content of rainfall as a tool to jointly estimate the groundwater recharge zone and transit times in the Ordesa and Monte Perdido National Park aquifer system, north-eastern Spain. Sci. Total Environ. 573, 505-517. https://doi.org/10.1016/j.scitotenv.2016.08.117.

Kovacs, G., 1978. Hydrology and water control on large plains. Hydrol. Sci. J. 23 (3), 305-332. https://doi.org/10.1080/02626667809491807.

Kyounghee, Kim, Xuhui, L., 2011. Isotopic enrichment of liquid water during evaporation from water surfaces. J. Hydrol. 399 (3-4), 364-375.

Lavado, R., Taboada, M., 1988. Soil water, salts, and sodium dynamics in a Natraquoll of Argentina. Catena 15, 577-594.

Ma, B., Jin, M., Liang, X., Li, J., 2018. Groundwater mixing and mineralization processes in a mountain-oasis-desert basin, northwest China: hydrogeochemistry and environmental tracer indicators. Hydrogeol. J. 26, 233-250. https://doi.org/10.1007/s10040017-1659-0.

Martínez, D., Quiroz Londoño, M., Dapeña, C., Glok Galli, M., Massone, H., Ferrante, A., 2011. Caracterización isotópica e hidroquímica de las precipitaciones en el sector sur de Tandilia. Proceedings VII Congreso Argentino de Hidrogeología y V Seminario Hispano-Latinoamericano Sobre Temas Actuales de la Hidrología Subterránea. Calidad y Contaminación de Agua Subterránea. Salta, Argentina, pp. 369-376.

Martínez, D., Quiroz Londoño, M., Bocanegra, E., Massone, H., Dapeña, C., 2013. Isotopes tracing the water cycle in the Pampeano Aquifer at the southeast of Buenos Aires province, Argentina. Proceedings Isotopes in Hydrology, Marine Ecosystems and Climate Change Studies, Vienna, pp. 177-183.

Martínez, D., Quiroz Londoño, O., Solomon, D., Dapeña, C., Massone, H., Benavente, M., Panarello, H., 2016. Hydrogeochemistry, isotopic composition and water age in the hydrologic system of a large catchment within a plain humid environment (Argentine Pampas): Quequén Grande River, Argentina. River Res. Appl. 33, 438-449.

Mayr, C., Lücke, A., Stichler, W., Trimborn, P., Ercolano, B., Oliva, G., Zolitschka, B., 2007. Precipitation origin and evaporation of lakes in semi-arid Patagonia (Argentina) inferred from stable isotopes ( $8180,82 \mathrm{H})$. J. Hydrol. 334, 53-63.

McEwan, K., Jolly, I., Holland, K., 2006. Groundwater - surface water interactions in arid/ semi-arid wetlands and the consequences of salinity for wetland ecology. CSIRO Land and Water Science Report 53/06, p. 43.

Migueltorena, M., Entraigas, I., D’Álfonso, C., Scaramuzzino, R., 2009. Introducción al estudio de los bajos dulces y alcalinos de la cuenca del arroyo del Azul (Buenos Aires). II Jornadas Argentinas de Ecología de Paisajes, Córdoba. p. 60.

Oiro, S., Comte, J., Soulsby, C., Walraevens, K., 2018. Using stable water isotopes to identify spatio-temporal controls on groundwater recharge in two contrasting East African aquifer systems. Hydrol. Sci. J. 63, 862-877.

Oyarzún, R., Zambra, S., Maturana, H., Oyarzún, J., Aguirre, E., Kretschme, N., 2016. Chemical and isotopic assessment of surface water-shallow groundwater interaction in the arid Grande river basin, North-Central Chile. Hydrol. Sci. J. 61 (12), 2193-2204. https://doi.org/10.1080/02626667.2015.1093635.

Panarello, H., Albero, M., 1983. Tritium, oxygen-18 and deuterium contents of Buenos Aires rainwater. Proceedeings Coloquio Internacional de Grandes Llanuras, Olavarría (Buenos Aires). vol. 2. UNESCO, pp. 889-898.

Panarello, H., Parica, C., 1984. Isótopos del oxígeno en hidrogeología e hidrología. Primeros valores en aguas de lluvia de Buenos Aires. Rev. Asoc. Geol. Argent. 39 (1-2), 3-11.

Panarello, H., Araguas-Araguas, L., Gerardo Abaya, J., Gibert, E., 1998. The role of the "global network for isotopes in precipitation, GNIP, in hydrological and hydroclimatic studies". Key Note. Proceedings International Symposium on Isotope Techniques in the Study of Past and Current Environmental Changes in the Hydrosphere and the Atmosphere, Vienna, pp. 79-91.

Peng, T., Chen, K., Zhan, W., Lu, W., Tong, L., 2015. Use of stable water isotopes to identify hydrological processes of meteoric water in montane catchments. Hydrol. Process. 29, 4957-4967.

Qian, H., Wu, J., Zhou, Y., Li, P., 2014. Stable oxygen and hydrogen isotopes as indicators of lake water recharge and evaporation in the lakes of the Yinchuan Plain. Hydrol. Process. 28, 3554-3562.

Quiroz Londoño, O., Martínez, D., Dapeña, C., Massone, H., 2008. Hydrogeochemistry and isotopes of groundwater in low gradients catchments of the province of Buenos Aires Argentina. HydrogeologyJournal 16, 1113-1127.

Quiroz Londoño, O., Martínez, D., Massone, H., Bocanegra, E., Ferrante, A., 2011. Caracterización isotópica del acuífero pampeano en la cuenca. Proceedings VII Congreso Argentino de Hidrogeología, Salta, Argentina. pp. 92-99.

Quiroz Londoño, M., Martínez, D., Massone, H., Londoño Ciro, L., Dapeña, C., 2015. Spatial distribution of electrical conductivity and stable isotopes in groundwater in large catchments: a geostatistical approach in the Quequén Grande River catchment, 
Argentina. Isot. Environ. Health Stud. 51 (3), 411-425. https://doi.org/10.1080/ 10256016.2015.1056740.

Romanelli, A., Quiroz Londoño, M., Massone, H., Martínez, D., Bocanegra, E., 2010. El agua subterránea en el funcionamiento hidrológico de los humedales del Sudeste Bonaerense, Provincia de Buenos Aires, Argentina. Bol. Geol. Min. 121, 373-386.

Sala, J., Kruse, E., Aguglino, R., 1987. Investigación hidrogeológica de la Cuenca del arroyo Azul, Provincia de Buenos Aires. Unpublishedtechnicalreport. Comisión de Investigaciones Científicas, La Plata, p. 235.

Salamalikis, V., Argiriou, A.A., Dotsika, E., 2016. Isotopic modeling of the sub-cloud evaporation effect in precipitation. Sci. Total Environ. 544, 1059-1072.

Sarochar, R., Ciappesoni, H., Ruiz, N., 2005. Precipitaciones convectivas y estratiformes en la Pampa Húmeda: una aproximación a su separación y aspectos climatológicos de ambas. Meteorológica 30, 77-88.

Singh, M., Kumar, S., Kumar, B., Singh, S., Singh, I., 2013. Investigation on the hydrodynamics of Ganga Alluvial Plain using environmental isotopes: a case study of the Gomati River Basin, northern India. Hydrologeol. J. 21, 687-700.

Taboada, M.A., 2006. Soil Structural Behavior in Flooded and Agricultural Soils of the Argentine Pampas. (Ph.D). Institut National Polytechnique de Toulouse, p. 361.

UNESCO, 2011. United Nations World Water Assessment Programme/UN-Water. The impact of global change on water resources: the response of UNESCO's International Hydrological Programme. Available from. https://unesdoc.unesco.org/ark:/48223/ pf0000192216.

Usunoff, E., Varni, M., Weinzettel, P., Rivas, R., 1999. Hidrogeología de grandes llanuras: La Pampa Húmeda Argentina. Bol. Geol. Min. 100 (4), 391-406.

Varela, L., Laurencena, P., Kruse, E., Deluchi, M., Rojo, A., 2002. Reconocimiento de la relación aguas superficiales-aguas subterráneas en el arroyo del Gato, provincia de Buenos Aires, Argentina. Proceedeings Aguas Subterráneas y Desarrollo Humano, Mar del Plata, Argentina http://sedici.unlp.edu.ar/handle/10915/26568.

Varni, M., 2013. Application of several methodologies to estimate groundwater recharge in the Pampeano Aquifer, Argentina. Water Technol. Sci. 4 (3), 63-80.

Varni, M., Custodio, E., 2013. Estimación de la recarga al acuífero del Azul: 1. Análisis de las características climáticas. In: González, N., Kruse, E., Trovatto, M., Laurencena, P. (Eds.), Agua Subterránea Recurso Estratégico. vol. 1. Editorial de la Universidad de La Plata (Edulp), La Plata, Tomo, pp. 31-37.

Varni, M., Comas, R., Weinzettel, P., Dietrich, S., 2013. Application of the water table fluctuation method to characterize groundwater recharge in the Pampa plain, Argentina. Hydrol. Sci. J. 58, 1445-1455. https://doi.org/10.1080/02626667.2013.833663.

Vazquez, P., Zulaica, L., Requesens, E., 2016. Environmental analysis of land use changes in the district of Azul (Buenos Aires, Argentina). Agriscientia 33 (1), 15-26.
Wiebe, K., et al., 2015. Climate change impacts on agricultura in 2050 under a range of plausible socioeconomic and emissions scenarios. Environ. Res. Lett. 10, 085010. https://doi.org/10.1088/1748-9326/10/8/085010.

Wu, X., Wang, X., Wang, Y., Hu, B., 2017. Water resources in the BadainFijaran Desert, China: new insight from isotopes. Hydrol. Earth Syst. Sci. https://doi.org/10.5194/ hess-2016-692.

Yin, L., Hou, G., Su, X., Wang, D., Dong, J., Hao, Y., Wang, X., 2011. Isotopes ( $\delta$ D and $\delta 180$ ) in precipitation, groundwater and surface water in the Ordos Plateau, China: implications with respect to groundwater recharge and circulation. Hydrogeol. J. 19, 429-443. https://doi.org/10.1007/s10040-010-0671-4.

Yuan, F., Sheng, Y., Yao, T., Fan, C., Li, J., Zhao, H., Lei, Y., 2011. Evaporative enrichment of oxygen-18 and deuterium in lake waters on the Tibetan Plateau. J. Paleolimnol. 46, 291-307.

Zabala, M.E., 2013. El origen de la composición química del acuífero freático en la cuenca del arroyo del Azul. (Ph.D thesis). UNC, p. 490 (Unpublished).

Zabala, M.E., Varni, M., Weinzettel, P., Ainchil, J., 2009. Aportes al conocimiento del subsuelo de la cuenca del arroyo Azul mediante la aplicación de métodos geoeléctricos. Proceedings VI Congreso Argentino de Hidrogeología, IV Seminario Hispanoamericano de temas actuales de la Hidrogeología, Santa Rosa (La Pampa). vol. 1, pp. 329-338.

Zabala, M.E., Manzano, M., Varni, M., Weinzettel, P., 2011. On the sources of salinity in groundwater under plain areas. Insights from $180,2 \mathrm{H}$ and hydrochemistry in the Azul River basin, Argentina. Proceedings International Symposium on Isotopes in Hydrology, Marine Ecosystems, and Climate Change Studies, Mónaco. vol. 1, pp. 287-294.

Zabala, M.E., Manzano, M., Vives, L., 2015. The origin of groundwater composition in the Pampeano Aquifer underlying the Del Azul Creek basin, Argentina. Sci. Total Environ. 518, 168-188. https://doi.org/10.1016/j.scitotenv.2015.02.065.

Zabala, M.E., Manzano, M., Vives, L., 2016. Assessment of processes controlling the regional distribution of fluoride and arsenic in groundwater of the Pampeano Aquifer in the Del Azul Creek basin (Argentina). J. Hydrol. 541, 1067-1087. https://doi.org/ 10.1016/j.jhydrol.2016.08.023.

Zabala, M.E., Sánchez Murillo, R., Dietrich, S., Gorocito, M., Vives, L., Manzano, M., Varni, M., 2020. Hydrological dataset from a large sub-humid plain. Mendeley Data v1. 10.17632/b34kg4jx7r.1.

Zárate, M., Mehl, A., 2010. Geología y geomorfología de la cuenca del arroyo del Azul, provincia de Buenos Aires, Argentina. In: Varni, M., Entraigas, I., Vives, L. (Eds.), Hacia la Gestión Integral de los Recursos Hídricos en Zonas de Llanura. Editorial Martín, Mar del Plata, pp. 65-78. 